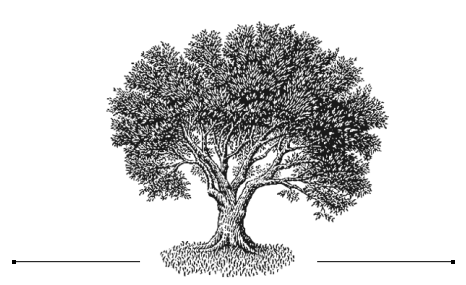

Скандинавский

остров

в славянской

языковой среде.

Диалект села

Старошведское: имя

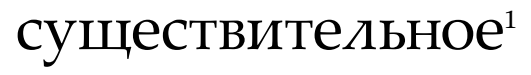

\author{
Александр Евгеньевич Маньков \\ Православный Свято-Тихоновский \\ гуманитарный университет, Москва
}

\section{A Scandinavian Island in a Slavonic Linguistic Environment. The Dialect of Gammalsvenskby: Nouns}

\author{
Alexander E. Mankov \\ St. Tikhon's Orthodox University, \\ Moscow
}

\title{
Резюме
}

Статья открывает серию публикаций, посвящённых морфологии диалекта с. Старошведское (шв. Gammalsvenskby), который является единственным живым скандинавским диалектом на территории бывшего СССР. Диалект Старошведского интересен для славистов как пример языкового острова в славянском окружении, так как со второй половины XX в. основным языком всех жителей села, включая носителей диалекта, является суржик. В связи с полным отсутствием исследований современного состояния диалекта и крайне небла-

1 Работа выполнена при поддержке Фонда фундаментальных лингвистических исследований (http://www.ffli.ru), проект A-32 «Диалект села Старошведское (Gammalsvenskby): полевое исследование».

Сбор материала для этой работы был начат в рамках международной научной сети «Шведская колония на Украине», организованной Сёдертёрнским университетом (Södertörn University College, Stockholm). Экспедиции в село 2004-2009 гг. финансировались фондами Baltic Sea Foundation of Sweden и Swedish Institute, Швеция.

Выражаю благодарность в содействии проекту директору Российскошведского центра РГГУ Т. А. Тоштендаль-Салычевой, являющейся инициатором изучения диалекта. 
гополучной ситуацией, в которой он в настоящее время находится, первоочередной задачей является сбор, классификация и введение в научный оборот фактического материала по фонетике, морфологии, синтаксису и лексике. Источником материала являются интервью с носителями консервативного варианта диалекта, записанные автором в ходе полевой работы в селе в 2004-2012 гг. В данной статье впервые предпринята исчерпывающая на данный момент публикация синхронного материала по имени существительному: приводятся все встретившиеся в интервью существительные мужского рода, относящиеся к типу 1а, даются примеры их употребления, соответствия из родственных диалектов, а также пояснения сравнительно-исторического характера. В последующих статьях планируется аналогичным образом опубликовать существительные остальных типов.

\section{Ключевые слова}

документирование исчезающих языков, исчезающий язык, полевая лингвистика, славяно-германские языковые контакты, шведские диалекты, восточношведские диалекты, шведские диалекты Эстонии, село Старошведское, диалектная морфология, диалектный словарь

\section{Abstract}

This paper initiates a series of publications on the morphology of the dialect of Staroshvedskoye (Sw. Gammalsvenskby), which is the only surviving Scandinavian dialect on the territory of the former Soviet Union. The village of Staroshvedskoye is located in the Kherson region, Ukraine. Its Swedish dialect historically belongs to the group of Swedish dialects of Estonia and goes back to the dialect of the island of Dagö (Hiiumaa). The dialect of Gammalsvenskby is of interest to slavists as an example of a language island in the Slavonic environment. From around the 1950s, the main spoken language of all village residents, including dialect speakers, has been surzhik. Due to the complete lack of studies of the present-day dialect and because of the severe endangerment in which the dialect is currently situated, the most urgent task is to collect, classify and publish the factual material. This paper introduces comprehensive material on nouns in the conservative variety of the present-day dialect. It lists all masculine nouns of type 1a together with their cognates from Estonian Swedish dialects; comments on the history of the forms are given as well. The sources for the material presented here are interviews with speakers of the conservative variety of the dialect recorded by the author during fieldwork in the village from 2004 to 2012. We plan to publish nouns of other types in later articles.

\section{Keywords}

documentary linguistics, endangered language, field linguistics, Slavic-Germanic language contact, Swedish dialectology, East Swedish dialects, Swedish dialects of Estonia, the village of Gammalsvenskby, dialect morphology, dialect vocabulary 


\section{ВВЕДЕНИЕ}

Сведения о с. Старошведское и о проекте по изучению его диалекта

§ 1. Село Старошведское находится на Украине, в Херсонской области (в XIX в. - Старошведская волость Херсонского уезда Херсонской губернии), на берегу Днепра ${ }^{2}$. Оно было основано в 1782 г. переселенцами с острова Да́гё (шв. Dagö; эстонское название - Hiiumaa). В то время остров входил в состав Российской империи; сейчас он принадлежит Эстонии. В XVIII в. Новороссийский край был малонаселён, и правительство Екатерины II предпринимало усилия к его заселению, в том числе иностранцами. Переселение шведов с Дагё было частью процесса колонизации Новороссийского края. Родным языком основателей села был не литературный шведский того времени, а диалект о. Дагё, который является одним из шведских диалектов Эстонии. Таким образом, диалект Старошведского восходит к диалекту о. Дагё. Число первопоселенцев составляло 880 человек [ПисАРЕвский 1899: 249]. Перед революцией число шведов составляло 718 человек [СПисок НАСЕлёНнЫХ МЕСТ ХЕРСОНСКОЙ ГУБЕРНИИ 1917: 126]. В настоящее время общее число лиц, хотя бы в минимальной степени владеющих диалектом, не превышает двадцати человек. Все носители консервативного варианта диалекта - женщины не моложе семидесяти лет. Обзор истории села и сведения о лингвистической ситуации в нём см. в статье [МАньков 2010А].

Диалект Старошведского интересен для славистов как пример языкового острова в славянском окружении. До переселения шведов с Дагё в XVIII в. их диалект находился в контакте с эстонским языком, в течение всего XIX в. и вплоть до середины XX в. - с немецким. Последнее обстоятельство связано с тем, что по соседству со Старошведским было несколько немецких поселений. Отметим, что в XIX в. число иностранных колонистов в Новороссийском крае было очень велико, причём большинство из них составляли немцы. В 1838 г. только в одной Херсонской губернии было 39 немецких колоний [ЗАБлоцкий 1838: 5-6]. К середине ХІХ в. Херсонская губерния представляла собой многонациональную область, что видно по статистическим данным о нерусском населении этой губернии в 1852 г.: “молдаван -75000 , бол-

2 Старошведское является историческим, а не официальным названием села. Официальное современное название - Змї̈вка. В конце XVIII в. по соседству было основано поселение немецких колонистов Schlangendorf (по-русски Змеевка, из за обилия змей в днепровских заливных лугах). Немцы называли шведскую колонию Altschwedendorf. Старошведское - перевод этого немецкого названия. В русских документах и публикациях XIX в. село называется либо Альтшведендорф, либо Старошведское. Нынешние носители диалекта называют село Svänskbin или Gamöl svänskbin ['gamœr 'svenskbi:n]. Gammalsvenskby - то же название на стандартном шведском. В советский период Старошведское и Шлангендорф были объединены в одно село, названное по-украински Зміївка. 
гар -11 132, сербов -436 , поляков -850 , греков - 3500 , армян -1990 , немцев - 31700 , шведов - 168, евреев талмудистов - 22424 , караимов - 446, цыган - 2516, всего 150162 ”. Общее число шведов в Российской Империи в 1852 г. составляло 11470 человек [Список иноРодцАм ЕвропЕйской России 1852]. По данным “Новороссийского календаря на 1865 г.”, в губерниях южного края России (Херсонская, Екатеринославская, Таврическая губернии, Бессарабская область) число “немцев с незначительным числом шведов и швейцарцев” составляло 151925 человек, тогда как число русских составляло 13162 человек [НоворосСИЙСКИЙ КАЛЕНДАРЬ 1864: 121].

Приблизительно со второй половины XX в. основным языком всех жителей села, включая носителей диалекта, является суржик, смесь русского и украинского. Существенно, что у некоторых из носителей диалекта родителями (или одним из родителей) были немцы. Преобладающим языком повседневного общения современных носителей диалекта является русско-украинский; все носители в той или иной степени владеют немецким, а также стандартным шведским. Ситуация многоязычия, как кажется, отражается прежде всего на среднекомпетентных носителях диалекта (т. е. носителях со средним уровнем владения диалектом; в английской терминологии - semi-speakers), так как пробелы в знании диалекта должны компенсироваться из других источников. Конкретные явления в диалекте Старошведского, вызванные этой ситуацией, требуют особого исследования ${ }^{3}$. Однако в настоящее время первоочередной задачей является сбор и публикация фактического материала для выполнения базового описания фонетики, грамматики и лексики диалекта. Это создаст основу для более глубокого изучения явлений языкового контакта, в том числе скандинавско-славянского. В предлагаемой статье мы впервые предпринимаем подробную публикацию имён существительных в диалекте: приводятся практически все известные на данный момент существительные мужского рода типа 1а (к этому типу относится большинство существительных мужского рода).

В 2004 г. Сёдертёрнским университетом (Södertörn University College, Швеция) была организована научная сеть «Старошведское: шведская колония на Украине». В рамках этого проекта в 2004 г. состоялась первая поездка автора данной статьи в Старошведское. В отличие от истории села, о диалекте в момент первой поездки не было известно ничего: сохраняется ли он, что собой представляет, кто на нём говорит? Никаких систематических исследований диалекта не проводилось с начала

Обзор общих вопросов, связанных с этой проблематикой, см., например, в статье [O’SHANNESSY 2011]. 
XX в. вплоть до начала нашей работы в 2004 г.; соответственно, в лингвистической литературе (как российской, так и зарубежной, в том числе шведской) нет никаких сведений о современном состоянии диалекта. В результате экспедиции 2004 г. стало ясно, что диалект сохранился как целостная языковая система (подробнее о проекте см. [МАньков 2011c]). На данный момент опубликован обзор фонетики диалекта [МАньков 2010A], базовое описание словоизменения [МАньков 2010в; 2011А; 2011в; 2012А], описание суффиксального словообразования существительных [МАньков 2012в; 2013А]. Эти работы посвящены консервативному варианту диалекта, т. е. основаны на материале интервью с носителями, обладающими высоким уровнем языковой компетенции. Исследование других вариантов диалекта и структурных изменений, происходящих в них, начато в статье [МАньков 2013в]; там же дана характеристика общей проблематики, связанной с морфологическими и лексическими изменениями в исчезающих языках.

В связи с полным отсутствием работ по современному состоянию диалекта единственным источником фактического материала являются устные интервью с носителями. Практически все формы, приведённые в данной работе, были названы Л. А. Утас, А. С. Лютко и М. Ф. Прасоловой, чей вариант диалекта отличается наибольшей устойчивостью системы словоизменения и сохранностью словаря. Большинство форм были неоднократно названы в разных интервью как минимум двумя носителями. Практически все интервью записаны цифровым диктофоном и хранятся в виде электронного аудиоархива. Если та или иная форма записана предшествующими исследователями (т. е. VENDELL'eм и KARLGREN'Oм; см. ниже) или засвидетельствована в родственных диалектах, но не была названа в интервью, она, естественно, не включается в материал современного диалекта и не учитывается при описании синхронной морфологии и лексики.

\section{Предшествующие исследования диалекта}

§ 2. Первоисследователем диалекта является выдающийся шведский диалектолог Херман Венде́лль. Он приезжал в село в 1881 г. и собрал там огромный лексический материал для «Словаря шведских диалектов Эстонии» [FREUDENTHAL, VENDELL 1886]. Этот словарь остаётся единственным опубликованным источником по лексике диалекта. Единственным опубликованным описанием грамматики диалекта является краткая статья Антона Карлгрена, написанная в 1906 г. и изданная в 1952 г. Нильсом Тибергом [KARLGREN 1953] ${ }^{4}$. Упомянем также монографию

4 Некоторый лексический материал приводится в другой его статье: [KARLGREN 1924]. 
H. Тиберга «Особенности эстонско-шведских диалектов» [TIBERG 1962]. Тиберг не приезжал в село, а интервьюировал тех носителей, которые в 1929 г. эмигрировали в Швецию. Данные Старошведского привлекаются им при интерпретации фонологических и морфологических явлений шведских диалектов Эстонии, однако систематического описания диалекта не даётся. Тиберг также является составителем картотеки шведских диалектов Эстонии, которая хранится в архиве Института языка и фольклора (Språk- och folkminnesinstitutet) в Уппсале.

Из родственных диалектов наиболее полно описан диалект Нюккё5, в настоящее время мёртвый. Информанты Карлгрена родились в 40-х и 60-80-х гг. XIX в., поэтому его данные относятся к совершенно другой эпохе и не могут служить источником для изучения синхронного состояния диалекта. В то же время эти данные (вместе с работами Венделля и Данелля) являются источником для истории диалекта и позволяют в общих чертах установить соотношение современного состояния словоизменения и словаря с их состоянием на конец XIX - начало XX в.

Обобщающей работой по шведским диалектам Эстонии является книга Э. Лагмана [E. LAGMAN 1979]. Базовыми работами по фонетике и грамматике восточно-шведских диалектов являются [HULTMAN 1894] и [Hultman 1939].

Необходимо отметить, что «Словарь шведских диалектов Эстонии» Венделля был встречен чрезвычайно резкой критикой со стороны шведских диалектологов; см., например, [DANELL 1905-1934: 8-13]. Детальное критическое рассмотрение материала по диалекту Старошведского, который представлен в этом словаре, будет дано нами в другой работе; здесь заметим только, что в отношении существительных недостатком этого словаря является неполная морфологическая характеристика: приводится только форма мн. ч., тогда как морфонологическая классификация требует также указания определённой формы ед. ч. [МАньков 2011А: §5]. В ходе наших интервью мы сверили бо́льшую часть словаря с данными трёх консервативных носителей. Если слово, приводимое Венделлем, известно носителям, то называемые ими формы в большинстве случаев совпадают с формами из словаря Венделля. Если имеют место фонетические и морфологические расхождения, то лишь в отдельных случаях их не удаётся объяснить лингвистическими причинами. Более существенной проблемой является значительное количество слов, неизвестных современным носителям. Следует, однако, учитывать, что материал Венделля собран в 1881 г. и отделён от наших интервью периодом более чем в 120 лет. В эпоху Венделля диалект был

5 Грамматики: [Vendell 1881; DANELL 1905-1934]. Словарь: [DANELl 1951]; дополнение к словарю: [ISBERG 1970]. 
основным средством общения для его носителей, тогда как для современных носителей он уже много десятилетий не является таковым. С учётом исторических условий, в которых находился диалект в XX в., расхождения между данными Венделля и современными данными представляются закономерными. Те неточности, которые предположительно допущены Венделлем, оправдываются пионерским характером и размахом его работы, которая к тому же была выполнена одним человеком в сравнительно короткий срок. Отметим, что словарь диалекта Нюккё [DANELL 1951] вышел спустя почти 50 лет после начала исследований Данелля, а словарные материалы Карлгрена и Тиберга так и не были доведены до публикации.

Организация фрактического материала

§ 3. Данные, приведённые ниже, организованы по следующей схеме:

1) диалектное существительное (с возможными фонетическими вариантами);

2) все известные композиты;

3) фразы из интервью, иллюстрирующие словоупотребление;

4) соответствия (если они известны) из предшествующих работ по шведским диалектам Эстонии; они отделены знаком $\|$.

Знак / разделяет фонетические варианты, // - морфологические.

В некоторых случаях мы посчитали возможным привести в качестве иллюстраций не только словосочетания и изолированные предложения, но и довольно развёрнутые повествования, что позволит читателю получить более общее представление о диалекте. В большинстве случаев после примеров словоупотребления указываются инициалы информанта:

АА - Анна Андреевна Аннас (род. 1936),

АЛ - Анна Семёновна Лютко (1931-2013),

ЛУ - Лидия Андреевна Утас (род. 1933),

МП - Мелитта Фридриховна Прасолова (род. 1926),

ЭУ - Эмма Ивановна Утас (род. 1932).

Что касается соответствий из предшествующих работ по шведским диалектам Эстонии, то в данной статье мы учитываем только важнейшие опубликованные работы: [FREUDENTHAL, VENDELL 1886; KARLGREN 1924; KARLGREN 1953; DANELl 1951; ISBERG 1970]. Это даёт возможность получить представление о морфологии и лексике современного диалекта в сравнительно-историческом контексте. Более подробные этимологические описания и развёрнутые перечни параллелей не являются нашей задачей в данный момент. Соответствия приводятся в их оригинальном виде, т. е. так, как они выглядят в соответствующих работах (см. §5). 
§ 4. Венделль использует следующие сокращённые обозначения диалектов: D - Dagö, G - Gammalsvenskby, N - Nuckö, O - Ormsö, R Rågö (LillR - Lilla Rågö, StorR - Stora Rågö), W - Wichterpal (Vippal). Haпример, DGNORW после какой-либо формы означает, что она записана в диалектах Дагё, Старошведского, Нюккё, Ормсё, Рогё, Виппаля. Эти сокращения сохранены нами при ссылках на словарь Венделля. Вместо полных форм мн. ч., приводимых Венделлем, мы даём только окончания (в случае, если корень существительного не меняется во мн. ч.). Переводы, совпадающие с переводом заглавного диалектного слова, не приводятся. Например, лемма 'рука' выглядит у Венделля следующим образом:

arm, pl. armar, m. Arm. DGNORW.

В данной статье это цитируется так:

arm, -ar m. DGNORW [FREUDENTHAL, VENDELl 1886: 17].

Что касается цитирования Данелля, то вместо индексов, обозначающих тип словоизменения, приводятся характерные для данного типа окончания. Например, у Данелля: $\operatorname{arm} \mathrm{m} .1$; в данной работе: $\mathrm{arm},-e n,-a r$, $-a \mathrm{~m}$. [DANELL 1951: 7].

\section{Принципы записи (орфоографрии)}

§ 5. Система записи, разработанная нами для современного диалекта: $a$

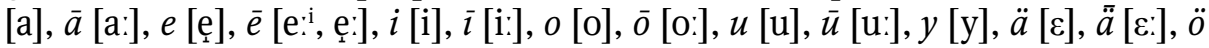

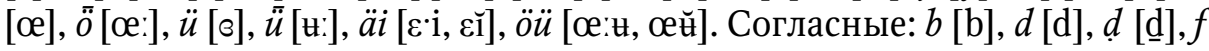
[f], $g$ [g], $h[\mathrm{~h}], j[\mathrm{j}], k[\mathrm{k}], l[\mathrm{l}], l[\mathrm{r}], m[\mathrm{~m}], n[\mathrm{n}]([\mathrm{v}]$ перед $k), n[\mathrm{n}], \eta[\mathrm{n}], p[\mathrm{p}]$, $r[\mathrm{r}], s[\mathrm{~s}], s\left[\int\right], t[\mathrm{t}], t[\mathrm{t}], v[\mathrm{v}], x[\mathrm{x}], z[\mathrm{z}], z$ [3]. Согласные $p, t, k$ являются неаспирированными; $d, t, n$ - постальвеолярные $d, t, n$. Сочетания $d j$, $g j, n j, s j, t j$ обозначают соответствующие палатализованные согласные; $s k j, s t j-\left[\mathrm{sk}^{\mathrm{j}}, \mathrm{st} \mathrm{t}^{\mathrm{j}}\right]$. Долгота согласных внутри морфем обозначается удвоением: hakk 'полоть'. Если долгий согласный находится перед другим согласным внутри морфемы, его долгота не обозначается, например vänt [ven:t] 'ждать'. На стыке морфем долгота обозначается, например tumm-t (форма среднего рода от tumm-är 'пустой'). Дефис используется при разделении элементов композитов, при отделении энклитических форм личных местоимений, на стыке слов при возникновении постальвеолярных согласных.

В предшествующих исследованиях шведских диалектов Эстонии использовались по меньшей мере три варианта записи диалектных форм:

- Орфография, разработанная Венделлем и применяемая в «Словаре шведских диалектов Эстонии» [FREUDENTHAL, VENDELL 1886]. Она основана на шведском и исландском алфавитах, с добавлением ряда 
особых букв (их фонетические значения см. в таблице ниже). Из ис-

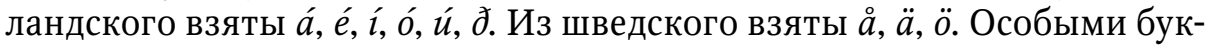
вами являются $\boldsymbol{d}, \boldsymbol{t}, \boldsymbol{s}, \boldsymbol{n}, \boldsymbol{l}, \boldsymbol{\lambda}, \boldsymbol{g}, \boldsymbol{g}, \dot{\boldsymbol{r}}, \partial, \dot{e}, \ddot{u}, \propto, Q, \varnothing$.

- Запись посредством landsmålsalfabetet («диалектный алфавит») применяется в работах Данелля [DANELL 1905-1934; 1951], Карлгрена [KARLGREN 1924; 1953], в «Словаре восточношведских диалектов» Венделля [VENDELL 1904-1907]. Landsmålsalfabetet - это шведский аналог IPA, т. е. система специфических знаков, созданная в 1878 г. для фонетической транскрипции шведских диалектов.

- Орфография, максимально приближенная к стандартной шведской, используется в более современных работах, например [TIBERG 1962; LAGMAN 1971A; E. LAGMAN 1979].

Разработанная нами система записи близка к третьему варианту, а именно к тому, который используется Х. Лагманом [LAGMAN 1971A: 23-24, 166-168]. В таблице ниже даны соответствия между системой записи в данной работе (первый столбец) и тремя названными вариантами. В последнем столбце приведены соответствующие символы IPA [HANDBOOK OF IPA 1999].

Гласные:

\begin{tabular}{|c|c|c|c|c|c|}
\hline & Венделль & $\begin{array}{c}\text { Карлгрен } \\
\text { (landsmåls- } \\
\text { alfabetet) }\end{array}$ & $\begin{array}{c}\text { Данелль } \\
\text { (landsmåls- } \\
\text { alfabetet) }\end{array}$ & Х. Лагман & IPA \\
\hline$a$ & $a$ & $a$ & $a$ & $a$ & $\mathrm{a}$ \\
\hline $\bar{a}$ & $a ́$ & $\underline{a}$ & $\underline{a}$ & $\bar{a}$ & $\mathrm{a}:$ \\
\hline$e$ & $e$ & $e$ & $e$ & $e$ & $\mathrm{e}$ \\
\hline- & $\dot{e}$ & - & - & $i, e$ & e \\
\hline $\bar{e}$ & $e^{\prime}$ & $\underline{e}$ & $\underline{e}$ & $\bar{e}$ & e: \\
\hline$i$ & $i$ & $\imath$ & $\imath$ & $i$ & $\mathrm{i}$ \\
\hline $\bar{\imath}$ & $i$ & $\underline{l}$ & $\underline{l}$ & $\bar{i}$ & $\mathrm{i}:$ \\
\hline- & - & - & $!$ & - & $\breve{1}$ \\
\hline 0 & 0 & $o$ & $O$ & $\stackrel{\circ}{a}$ & 0 \\
\hline$\overline{0}$ & $\stackrel{\circ}{a}$ & $\underline{Q}$ & $\underline{Q}$ & $\bar{a}$ & O: \\
\hline- & - & $a, \underline{a}$ & - & $\stackrel{\circ}{a}, \stackrel{\bar{a}}{a}$ & Q, Q: \\
\hline$u$ & $u$ & 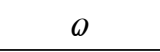 & o & $O$ & $\mathrm{u}$ \\
\hline $\bar{u}$ & ó & $\underline{\underline{Q}}$ & $\underline{\underline{Q}}$ & $\bar{o}$ & $\mathrm{u}:$ \\
\hline$\ddot{a}$ & $\ddot{a}$ & $e$ & $\not e$ & $\ddot{a}$ & $\varepsilon$ \\
\hline
\end{tabular}




\begin{tabular}{|c|c|c|c|c|c|}
\hline & Венделль & $\begin{array}{c}\text { Карлгрен } \\
\text { (landsmåls- } \\
\text { alfabetet) }\end{array}$ & $\begin{array}{c}\text { Данелль } \\
\text { (landsmåls- } \\
\text { alfabetet) }\end{array}$ & Х. Лагман & IPA \\
\hline- & - & $a$ & - & $\ddot{a}$ & $\varepsilon$ \\
\hline$\overline{\ddot{a}}$ & $a$ & $\underline{a}$ & $\underline{a}$ & $\bar{a}$ & $\varepsilon:$ \\
\hline$\ddot{o}$ & $\ddot{o}$ & $Q$ & - & $\ddot{o}$ & $œ$ \\
\hline$\overline{\ddot{O}}$ & $\ddot{o}$ & $\underline{Q}$ & - & $\overline{\bar{o}}$ & œ: \\
\hline- & $\varnothing$ & - & - & - & Ø: \\
\hline \multirow[t]{2}{*}{$\ddot{u}[\mathrm{o}]$} & \multirow[t]{2}{*}{$\ddot{u}[\theta / \mathrm{Y}]$} & $u[\mathrm{E} / \Theta]$ & \multirow[t]{2}{*}{$u[\mathrm{u} / \varnothing]$} & \multirow[t]{2}{*}{$\mathrm{u}[\mathrm{\theta} / \mathrm{u}]$} & $\begin{array}{c}\text { нет единого } \\
\text { значения }^{6}\end{array}$ \\
\hline & & $u$ & & & $\mathrm{H}$ \\
\hline $\bar{u}$ & $\dot{u}$ & $\underline{u}$ & $\underline{\underline{u}}[\mathrm{H}: / \varnothing:]$ & $\bar{u}$ & $H:$ \\
\hline- & $\partial$ & $\partial$ & - & - & $\partial$ \\
\hline$\ddot{a} i$ & $\ddot{a} i$ & $e \underline{i}$ & $a e i$ & $\ddot{a} i$ & $\varepsilon \mathrm{i}$ \\
\hline$\ddot{o u}$ & $\ddot{o u}$ & $Q \mu$ & - & - & $œ \sharp$ \\
\hline
\end{tabular}

Согласные:

\begin{tabular}{|c|c|c|c|c|c|}
\hline & Венделль & $\begin{array}{l}\text { Карлгрен } \\
\text { (landsmåls- } \\
\text { alfabetet) }\end{array}$ & $\begin{array}{c}\text { Данелль } \\
\text { (landsmåls- } \\
\text { alfabetet) }\end{array}$ & Х. Лагман & IPA \\
\hline$b$ & $b$ & $b$ & $b$ & $b$ & $\mathrm{~b}$ \\
\hline- & - & 6 & - & - & $\beta$ \\
\hline$d$ & $d$ & $d$ & $d$ & $d$ & $\mathrm{~d}$ \\
\hline$d$ & \multirow{2}{*}{$d$} & $d$ & $d$ & $d$ & $\underline{\mathrm{d}}$ \\
\hline- & & $d$ & - & - & $\mathrm{d}$ \\
\hline- & ઇ & $\partial$ & - & - & ð \\
\hline
\end{tabular}

6 При записи современного диалекта буквой $\ddot{u}$ мы обозначаем [в], среднеоткрытый огубленный гласный среднего ряда. В отличие от стандартного шведского краткого $u$ [ө], при произнесении [ө] губы выдвигаются вперёд; кроме того, [ө] является более открытым. Возможно, однако, произнесение этого гласного как [घ] (особенно в интервью с ЛУ). Предшествующие исследователи диалекта не дают точного определения артикуляции этого гласного. Венделль указывает, что он находится между шв. $u$ и $y$, Карлгрен утверждает, что он отличается как от шв. $u$, так и от $\ddot{o}$, находясь по качеству приблизительно между этими гласными [Freudenthal, Vendell 1886: 8; KARLGRen 1953: § 12]. Символ $u$ у Карлгрена обозначает краткий эквивалент $\underline{u}$, возникающий только при сокращении $\underline{u}$ в первом элементе композитов [KARLGREN 1953: § 8]. В диалекте Нюккё $u$ произносится как [ø] рядом с $r$, [r] и постальвеолярными согласными, как [u] в остальных положениях [DANELL 1905-1934: § 6]. 


\begin{tabular}{|c|c|c|c|c|c|}
\hline & Венделль & $\begin{array}{c}\text { Карлгрен } \\
\text { (landsmåls- } \\
\text { alfabetet) }\end{array}$ & $\begin{array}{c}\text { Данелль } \\
\text { (landsmåls- } \\
\text { alfabetet) }\end{array}$ & Х. Лагман & IPA \\
\hline$f$ & $f$ & $f$ & $f$ & $f$ & f \\
\hline$g$ & $g$ & $g$ & $g$ & $g$ & $\mathrm{~g}$ \\
\hline$\eta$ & $y$ & $y$ & $y$ & $n g$ & $\eta$ \\
\hline$h$ & $h$ & $h$ & $h$ & $h$ & $\mathrm{~h}$ \\
\hline$x$ & - & $x$ & - & - & $\mathrm{X}$ \\
\hline- & - & $y$ & - & - & ç \\
\hline$j$ & $i$ & $i$ & $j$ & $i$ & $\mathrm{j}$ \\
\hline$k$ & $k$ & $k$ & $k$ & $k$ & $\mathrm{k}$ \\
\hline$l$ & $l$ & $l$ & $l$ & $l$ & 1 \\
\hline$l$ & $l$ & 4 & lr & $l$ & $\mathrm{r}$ \\
\hline- & $\lambda$ & - & $l$ & $h l$ & 1 \\
\hline$m$ & $m$ & $m$ & $m$ & $m$ & $\mathrm{~m}$ \\
\hline- & - & $w$ & - & - & $\mathrm{m}$ \\
\hline$n$ & $n$ & $n$ & $n$ & $n$ & $\mathrm{n}$ \\
\hline$n$ & \multirow{2}{*}{$n$} & - & $\eta$ & $n$ & $\underline{\mathrm{n}}$ \\
\hline- & & $n$ & - & - & $\eta$ \\
\hline$p$ & $p$ & $p$ & $p$ & $p$ & $\mathrm{p}$ \\
\hline$r$ & $r$ & $r$ & $r$ & $r$ & $r$ \\
\hline- & $\dot{r}$ & - & - & - & $\mathrm{R}$ \\
\hline$s$ & $s$ & $s$ & $s$ & $s$ & $S$ \\
\hline$\underline{s}$ & - & - & - & - & $\int$ \\
\hline- & \multirow{2}{*}{$\boldsymbol{s}$} & $S$ & $S$ & $\underline{s}$ & $\underline{S}$ \\
\hline- & & $S$ & - & - & $\mathrm{S}$ \\
\hline$t$ & $t$ & $t$ & $t$ & $t$ & $\mathrm{t}$ \\
\hline$t$ & \multirow{2}{*}{$t$} & $t$ & $t$ & $t$ & $\underline{\mathrm{t}}$ \\
\hline- & & 4 & - & - & $t$ \\
\hline$v$ & $v$ & $v$ & $v$ & $v$ & $\mathrm{~V}$ \\
\hline- & $w$ & - & - & - & $\mathrm{W}$ \\
\hline$z$ & $z$ & - & - & - & $\mathrm{Z}$ \\
\hline$z$ & - & - & - & - & 3 \\
\hline
\end{tabular}


Фонетические расхождения между формами, записанными Венделлем и Карлгреном, и формами современного диалекта

§ 6. Перечислим те фонетические расхождения между формами, записанными Венделлем, и соответствующими формами из проведённых нами интервью, которые имеют регулярный характер.

\begin{tabular}{|c|c|}
\hline $\begin{array}{c}\text { У Венделля } \\
\text { (примеры приводятся в его орфографии) }\end{array}$ & В современном диалекте \\
\hline $\begin{array}{l}\text { ઇ [ð], например, kaðəs ‘фуражка’, } \\
\text { kaðufl ‘картофель’, júð‘еврей’ }\end{array}$ & $\begin{array}{l}\text { Согласный Ә не встретился в интер- } \\
\text { вью. В соответствующих словах на } \\
\text { его месте встречаются } d, d, t, t, t: \\
\text { kadus/kaḍos/kațüs, kaḍ(ü)fl/katüfl, jü } d\end{array}$ \\
\hline $\begin{array}{l}\boldsymbol{n} \text { внутри морфем (постальвеоляр- } \\
\text { ное или ретрофлексное } n \text {, т. е. [n, n]): } \\
\text { bión 'медведь', kén 'зёрнышко' }\end{array}$ & Дентальное $n: b j u \bar{n} n, k \bar{e} n$ \\
\hline 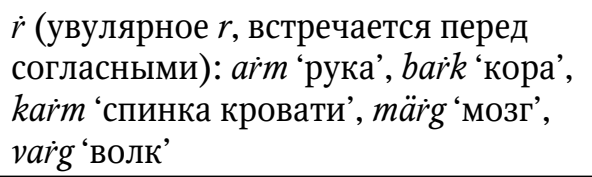 & $\begin{array}{l}\text { Переднеязычное } r \text { (как в русском): } \\
\text { arm, bark, karm, märg, varg }\end{array}$ \\
\hline $\begin{array}{l}w \text { [w]: kalw'телёнок’, korww ‘колбаса’, } \\
\text { kwast 'метла’ }\end{array}$ & v: kalv, korv, kvast \\
\hline $\begin{array}{l}\lambda l \text { - (глухое } l+\text { обычное } l \text {, в начале } \\
\text { слова): } \lambda l e a \text { 'сани' }\end{array}$ & sl-: släa \\
\hline 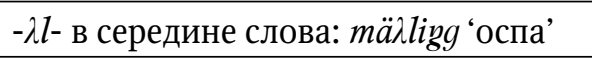 & $-x l-: m \ddot{a} x l i \eta$ \\
\hline 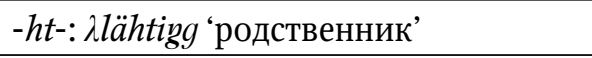 & ft: släftin \\
\hline $\begin{array}{l}y g \text { [ng]: draegg ‘работник’, rigg } \\
\text { ‘кольцо’, vigg ‘крыло’, vargugg } \\
\text { 'волчонок’, kriggäl ‘баранка’ }\end{array}$ & 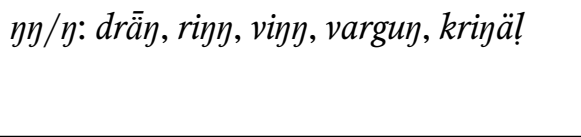 \\
\hline $\begin{array}{l}\text { di-, ti-, si-: diúpläik ‘глубина', tiú } \\
\text { 'вор', tiúr ‘бык’, si\&l 'душа' }\end{array}$ & $\begin{array}{l}\text { Палатализованные согласные: } \\
\text { djüpläik, tjüu, tjüur, sjöll }\end{array}$ \\
\hline $\begin{array}{l}\dot{e} \text { (закрытое e, встречается только в } \\
\text { безударных слогах): svänskén, } \\
\text { svänskér, svänske формы от svänsk } \\
\text { 'швед’, rissér мн. ч. от riss ‘русский’, } \\
\text { fiskiarér, fiskiare мн. ч. от fiskiar } \\
\text { 'рыбак', ivedäil ‘накидка, платок’ }\end{array}$ & $\begin{array}{l}\text { 1) В безударых слогах не перед } r \\
\text { гласный е всегда является закры- } \\
\text { тым, поэтому нет необходимости в } \\
\text { его особом обозначении: svänsken, } \\
\text { svänske, fiskjare, ive-däil, } \\
\text { 2) В положении перед r e произно- } \\
\text { сится открыто и обозначается } \ddot{a}: \\
\text { svänskär, rissär, fiskjarär }{ }^{7}\end{array}$ \\
\hline
\end{tabular}

7 Подробнее о распределении аллофонов безударного /е/ см. [МАньков 2010А: § 56]. 


\begin{tabular}{|c|c|}
\hline $\begin{array}{c}\text { У Венделля } \\
\text { (примеры приводятся в его орфографии) }\end{array}$ & В современном диалекте \\
\hline $\begin{array}{l}\text {-ər: iēgar ‘охотник’, kwēldar ‘вечер’, } \\
\text { stāvar ‘шест’, vintar ‘зима' }\end{array}$ & -är: jēgär, kvēldär, stāvär, vintär \\
\hline $\begin{array}{l}\text {-äl: gāväl ‘фронтон’, gäigäl ‘жабра’, } \\
\text { hummäl ‘хмель’, likäl ‘ключ’ }\end{array}$ & $\begin{array}{l}\text {-äl! наряду с -öl: gāvöl, gäigäl, hummöl, } \\
\text { liköl//likäl! }\end{array}$ \\
\hline 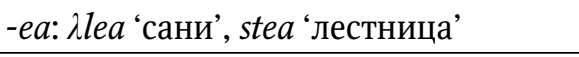 & -äa: släa, stäa \\
\hline 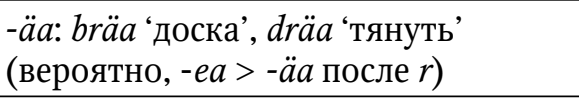 & -äa: bräa, dräa \\
\hline $\begin{array}{l}\text {-oa/-ua: boa/-bua ‘дуга', krova ‘во- } \\
\text { ротник’ (это написание отражает } \\
\text { произношение с глайдом), moa/mua } \\
\text { ‘желудок’ }\end{array}$ & -ōa c [ơ:]: bōa, krōa, mōa \\
\hline
\end{tabular}

§ 7. Регулярные фонетические расхождения между формами, приведёнными Карлгреном, и их соответствиями из проведённых нами интервью:

\begin{tabular}{|c|c|}
\hline $\begin{array}{c}\text { У Карлгрена } \\
\text { (примеры приводятся в landsmålsalfabetet) }\end{array}$ & В современном диалекте \\
\hline сеа, aа: brcea 'доска', таa 'желудок' & $\ddot{a}, o$ перед $a$ удлинились: $b r \bar{a} a, m \bar{o} a$ \\
\hline 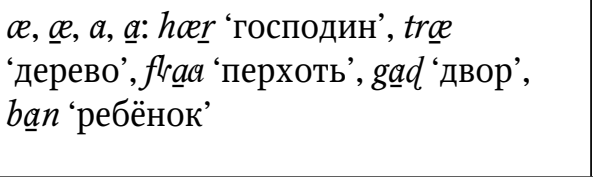 & 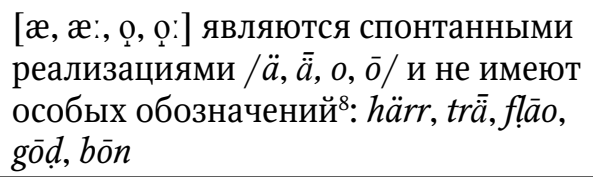 \\
\hline $\begin{array}{l}\text { Назализованные гласные: lawft } \\
\text { ср. p. от logger ‘длинный’, dęvd } \\
\text { претерит от degge ‘ударить', dręnft } \\
\text { претерит от dregke ‘утопить', Qwft } \\
\text { ср. р. от ogg- ‘молодой’ }\end{array}$ & $\begin{array}{l}\text { Отсутствуют; вместо них гласный } \\
+ \text { m: lāmft, dēmvd/dēmd, drämft, umft }\end{array}$ \\
\hline $6, \partial, w$ & Отсутствуют \\
\hline 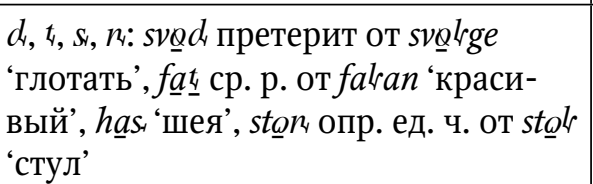 & $\begin{array}{l}\text { Отсутствуют; вместо них } \\
\text { постальвеолярные } d, t, n \text { и } \\
\text { альвеолопалатальное [S]: svōd, fatț, } \\
\text { hās, stūn }\end{array}$ \\
\hline
\end{tabular}

$8 \quad$ [IBID.: $\S \S 35,47]$. 
Типы склонения существительных мужского рода

§ 8. Для того чтобы записать парадигму и выяснить тип словоизменения, мы просили информантов назвать существительное в следующих словосочетаниях: с числительным/местоимением «один» (так устанавливается неопределённая форма ед. ч.); с местоимениями «этот/тот» (определённая форма ед. ч.); сместоимением тіke ‘много’ (неопределённая форма мн. ч.); с местоимениями «эти/те» (определённая форма мн. ч.).

Морфонологические типы существительных м. р. и характерные для них окончания приведены в таблице :

\begin{tabular}{|c|c|c|c|c|}
\hline Тип & Опр. ед.ч. & Мн. ч. & Опр. мн. ч. & Примеры \\
\hline m.1a & -en & \multirow{4}{*}{$-a r$} & \multirow{4}{*}{$-a / /-a n a$} & $\begin{array}{l}\text { fisk, fisk-en, fisk-ar, fisk-a//-ana } \\
\text { 'рыба' }\end{array}$ \\
\hline m.1b & $-n$ & & & $\begin{array}{l}\text { kvüst, kvüst-n, kvüst-ar, kvüst-a// } \\
\text { - ana 'ветка' }\end{array}$ \\
\hline m.1c & $-n$ & & & $\begin{array}{l}\text { stūl, stūn, stūl-ar, stūl-a//-ana } \\
\text { 'стул' }\end{array}$ \\
\hline m.1d & $-\varnothing$ & & & $\begin{array}{l}\text { bjūn, bjūn, bjūn-ar, bjūn-a//-ana } \\
\text { 'медведь' }\end{array}$ \\
\hline m.1e & $-e n$ & $-j-a r$ & $-j-a / /-j-a n a$ & $\begin{array}{l}\text { säkk, säkk-en, säkk-j-ar, säkk-j-a// } \\
\text {-j-ana 'мешок' }\end{array}$ \\
\hline $\mathrm{m} .2 \mathrm{a}$ & $-e n /-n /-\varnothing$ & $-\ddot{a r} / /-a r$ & $\begin{array}{l}\text {-e//-ena// } \\
\text {-a//-ana }\end{array}$ & $\begin{array}{l}\text { svänsk, svänsk-en, svänsk-är//-ar, } \\
\text { svänsk-e//-a//-ana 'швед' }\end{array}$ \\
\hline $\mathrm{m} .2 \mathrm{~b}$ & $-n$ & $-\ddot{a} r / /-\varnothing$ & $\begin{array}{l}-e / /-e n a / / \\
-n a\end{array}$ & $\begin{array}{l}\text { bokar, bokan, bokar-är, } \\
\text { bokar-e//bokana 'пекарь', } \\
\text { biggjar, biggjan, biggjar//biggjar- } \\
\text { är, biggjar-e//-ena 'строитель' }\end{array}$ \\
\hline m.3a & $-n$ & $-r$ & $-n a$ & $\begin{array}{l}\text { stoka, stoka-n, stoka-r, stoka-na } \\
\text { 'палка' }\end{array}$ \\
\hline m.3b & $-a n$ & $-a r$ & $-a n a / /-a$ & $\begin{array}{l}\text { ènd, ènd-an, ènd-ar, ènd-a//-ana } \\
\text { 'конец' }\end{array}$ \\
\hline $\mathrm{m} .4$ & $-n /-\varnothing$ & $\begin{array}{c}-\ddot{a} r \\
\text { с умлаутом }\end{array}$ & $\begin{array}{c}-r e / /-e \\
\text { с умлаутом }\end{array}$ & füt, füt-n, fèt-är, fèt-re 'нога' \\
\hline
\end{tabular}

В форме определённого ед. ч. существительные с окончанием -еп (типы 1, 2) противопоставлены существительным с -an/-n (тип 3). В неопределённом мн. ч. существительные с - $a r /-r$ (типы 1,3$)$ противостоят

9 Соотношение нашей классификации с классификациями Карлгрена и Данелля см. в [МАньков 2011А: $§ 15$ и сл.]. История окончаний рассмотрена в [МАньков 2010в]. 
существительным с - ӓr (тип 2). Тип 4 характеризуется умлаутом во мн. ч., а также окончанием -re в определённом мн. ч.

ТИП М.1

Подтип 1а

§ 9. Характерным признаком этого подтипа является аффикс -еn в определённом ед. ч. Сюда относятся существительные с исходами основ на любой согласный (кроме дентальных и $r, r r$, а также кроме $l$ и $l$, следующих после согласного или безударного гласного) и на любой ударный гласный [МАньков 2010в: 101]. Из существительных с основой на долгий гласный только $b \bar{i}, k \bar{o}, \operatorname{trō}$ встретились в проведённых интервью как с -en, так и с - $n$ в определённом ед. ч. Единственная форма, известная только с - $n$ в определённом ед. ч., $-h \bar{n} n$ (§ 10.49). У заимствованных существительных (прежде всего у тех, которые сохраняют морфонологические черты, нехарактерные для исконных слов) часто отсутствует особая форма определённого ед. ч., т. е. определённая форма ед. ч. совпадает с неопределённой [KARLGREN 1953: § 33, anm. 2; МАньков 2010в: § 13]. Из приведённых ниже существительных это касается ánsux, briff, pojke, șlaך.

§ 10. В интервью встретились следующие существительные подтипа 1a:

1. álesk 'галушка' (заимствование, восходящее к русскому): Toja kükar torr aleskar $_{\mathrm{MH}}$, to skär ja dom; to ja kükar sjürmölksalesk-väling, so plukkar ja dom: manlar ja 'ü̈t däien o skär rōndar, o sänn tār ja tom rōndana po äitta o plukkadom ЛУ 'Когда я готовлю сухие галушки, то я их режу; когда готовлю суп из кислого молока с галушками, то я их рву: раскатываю тесто и режу полоски и потом беру те полоски по одной и рву их’.

|l aleskar (мн. ч.) [KARLGREN 1924: 47].

2. ansux 'костюм' (< нем. Anzug m.): Klēe 'pō han ansux, ja skōar höșs-n passar ot de ЛУ 'Надень тот костюм, посмотрю как он подходит тебе'; Ja vil fräist täsn ansux, höș̣-n passar ōt me ЛУ 'Я хочу померить этот костюм, как он подходит мне'.

Исход на $x$ нехарактерен для исконных слов (ansux - единственное существительное м. р. с таким исходом), в связи с этим у данного существительного отсутствует особая форма определённого ед. ч.: han ansux, täsn ansux (а не *ansuxen); см. §9.

3. arm 'рука': unde armen 'подмышкой’; Armen kan änt bjü̈g-en ЛУ 'Рука, она не гнётся, я не могу согнуть её'; Ja brö̈̈t 'ó

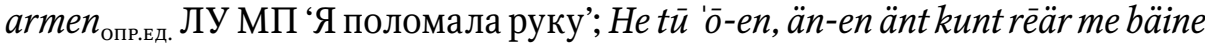
o armen $_{\text {опр.вд. }}$ hègär sia ЛУ 'Его парализовало, так что он не мог двигать ногой и рукой, правую сторону'. 
|| arm, -arm. DGNORW [FREUDENTHAL, VeNDELl 1886: 17]; arm, -en, -ar, $-a \mathrm{~m}$. [DANELL 1951: 7].

4. balk 'бревно' (< нем. Balken т. или шв. balk). В интервью с ЛУ это существительное встретилось с неопределённым артиклем ж. p. - äin $b a l k$, вероятно по ассоциации с рус. балка.

\| balk, -ar m. G (исконная форма, сохраняющая !) [FREUDENTHAL, VENDELl 1886: 20]; balk, -an, -ar, - $a$ m. [DANELl 1951: 16].

5. bark только ед. ч. 'кора': snēr 'ò barken или flō 'tjānd barken 'обдирать кору'; De flèt lill korga, so fō-de fḷo 'tjānd barken опр.ед.fron tom vidjana ЛУ 'Чтобы сплести маленькие корзинки, надо ободрать кору с лозин’; Strüssana jäta blānna o gnāvöl barken gräina ЛУ ‘Кролики едят листья и обгрызают кору с тех веток, а древесина остаётся'.

|| bark, -ar m. GNOW [FREUdENTHAL, VeNDELl 1886: 20]; bark, -en, -ar, - $a$ m. [DANELL 1951: 17].

6. barm 'грудь': Ja stuppa 'inn-e ot barmen 'Я засунула её (еду) за пазуху, чтобы она не замёрзла'.

\| barm, -ar m. DGNORW [FREUDENTHAL, VENDELL 1886: 21]; barm, -en, - $a r,-a$ m. [KARLGREN 1953: 17; DANELL 1951: 17].

7. bi 'село': Svänsk-bin 'Шведское село', Gamöl-svänskbin 'Старошведское’; herhä́im e bin 'тут в селе'; Nö jär änt ina arbet soṣs-som fär vār üte souxóz, nö jära dom sole bēndär. Nö fó-de bäăa, umm-en tār 'mūt-de näst se po arbete. Gō dom umm bin опр.в. o grāv katüfla näst folke ЛУ 'Сейчас нет работы как раньше было в совхозе, сейчас сами хозяева. Сейчас надо просить, чтобы кто-то взял к себе на работу. Ходят по селу и копают картошку у людей’; Bäitts änt mäiär 'ò me, konfrón tār ja he allt, gō umm bin опр.в. $о$ bäitts! ЛУ 'Больше не проси у меня, откуда я возьму всё это, иди по селу и проси!'; Hon gōr o

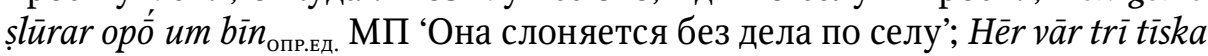

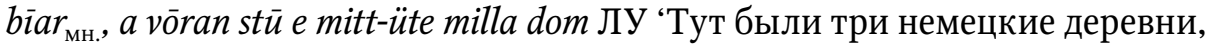
а наша стояла в середине между ними'.

Формы этого существительного, встретившиеся в интервью:

\begin{tabular}{|c|c|c|c|c|}
\hline & Ед. ч. & Опр. ед. ч. & Мн. ч. & Опр. мн. ч. \\
\hline МП & $b \bar{i}$ & bin & biar & bìana \\
\hline ЛУ & $b \bar{i}$ & bin & bïär, binar & bìa, biana \\
\hline АЛ & $b \bar{i}$ & bien & biar & biana \\
\hline ЭУ & \multicolumn{3}{|c|}{ bin } & \multicolumn{2}{|c|}{ bïär, binar } \\
\hline
\end{tabular}

Следует отметить колебание bin/bien в опр. ед. ч. Форма мн. ч. bï̈r может быть следом древнего склонения по типу $i$-основ м. p. (ср. др.исл. býr). Мн. ч. binar появилось вследствие переразложения *bi-na 
(фонетически закономерная форма) > *bin-a, откуда извлечена основа Мн. ч. bin- [МАньков 2010в: § 18]. В интервью с ЭУ - $n$ распространено на всю парадигму: än bìn и tfö binar: Ve hōa än stūr bìn 'У нас большое село'. Во мн. ч. ЭУ также не различает неопределённую и определённую форму: tfō stūr binar 'два больших села', tfō bï̈r 'два села' и tom bï̈r 'те сёла’ (в последнем случае должно быть опр. мн. ч.).

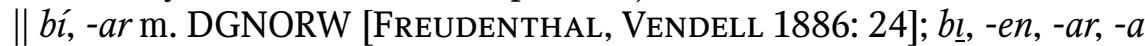
m. [KARLGREN 1953: 17; DANELl 1951: 61].

8. bïl 'автомобиль' (< шв. bil): Han komm 'inn näst-dom kērande, han hār sin äia bìl Лу 'Он заехал за ними, у него своя машина'; Tom kèr kolär um bìn, bilen опр.ед. töütar ЛУ 'Возят уголь по селу, машина гудит’; Ja släpa säkkjar

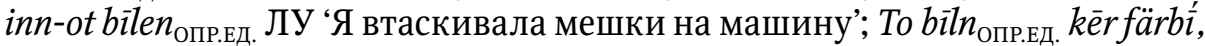
so jä̈-d̈̈r dōmb bait-n ЛУ 'Когда машина едет мимо, за ней пыль'; Han gī bait bìln Bìlar ${ }_{\mathrm{MH} .}$ kèr, so stivä-de ot sīa, gävär väg ot-dom ЛУ 'Машины ездят, отходишь в сторону, даёшь им дорогу'.

Это существительное колеблется между типами $1 \mathrm{a}$ и $1 \mathrm{~b}$ : как видно по примерам, в определённой форме ед. ч. -еп (тип 1a) встречается наряду с $-n$ (тип $1 b)$.

$\|$ bi $l,-n,-a r,-a$ m. [DANELL 1951: 24].

9. blikk в ӧ̈̈-blikk 'миг'

\| öublikk, -èr n. G, -ar m. D, также öugnablikk, -èr n. G [FREUDENTHAL,

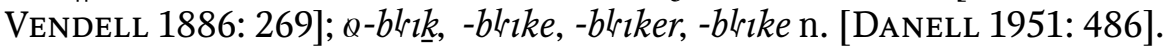

10. blipp “карандаш’: färg-blipp “цветной карандаш’; Gävän spitsa (также spitsandär) blipp ot me ‘Дай мне заточенный карандаш’; Ja spitsa blippen опр.ед. 'Я заточила карандаш'.

|| blípinn, -arf. GN [FREUdENTHAL, Vendell 1886: 25]; blı-pin, - $\varnothing,-a r$, - $a$ m., - $a$, -ar, -ana f. [DANELl 1951: 33]. Форма blipp в современном диалекте возникла из *bli -pinn (blī ‘свинец’ + pinn ‘колышек’). Исходная форма blipinn была воспринята как определённое ед. ч. и подверглась переразложению: *blipinn > *blip-en > blipp-en. Гласный $\bar{\imath}$ в первом элементе композита должен был сократиться, так как *bli-pinn дало бы *blip, а не blipp; о сокращении долгих гласных в композитах см. [МАньков 2010А: 22 (§ 52)]. Форма blipinn является калькой нем. Bleistift.

11. blumm 'цветы, цвет’ (coll.): hümmöl-blumm 'цветы хмеля’; Fäșt fōde kūk han hümmöl-blummen 'inn mōll... ЛУ 'Вначале надо варить цветы хмеля, слить воду, и в кипячёную воду мешаешь муку...' (об изготовлении дрожжей).

\| blumm только ед. ч., m. G [FREUdENTHAL, Vendell 1886: 26].

12. blü только ед. ч., также n. 'кровь’: Hon hustar mä blü ЛУ 'Она кашляет кровью’; То ja änt hār mitt äia blū, so tarvar ja änt främande ЛУ ‘Если у 
меня нет своей крови, мне не надо чужой' (о переливании крови); Han $k v i t$ blüen опр.ед. $_{\text {vann täföre han rē blüen опр.вд. }}$ tù 'ive ЛУ 'Белая кровь (белокровие) всё равно победила красную кровь, взяла верх’; Ja skār me e finä$r e, o b l \bar{u} e n_{\text {опр.е. }}$ rann so hōle ЛУ 'Я порезала палец, и сильно бежала кровь'.

Колеблется между мужским (blüen) и средним родом (mitt blü); подробнее об этом колебании см. [МАньков 2010в: 94 (§ 2)].

|| bló только ед. ч., m. DGNORW [FREUDENTHAL, VENDELL 1886: 26]; $b l_{\varrho},-e n,-a r,-a$ m. [DANELL 1951: 30].

13. boll 'мяч': kätt-boll 'котлета'; olljo-bollar (мн. ч.) 'пампушки'.

\| boll, -ar m. DGNO [FREUDENTHAL, VENDELL 1886: 28]; bol, - $a$, -ar, -ana f. [DANELl 1951: 36].

14. borr 'репей': Tom borra

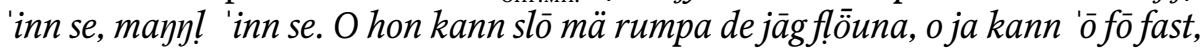
to ja sitär o mölkar. Före he fō-de plukk 'üt dom ЛУ 'Репейники набираются в хвост у коровы и запутываются, заматываются. Она может ударить хвостом, чтобы отогнать мух, и я могу тоже получить, когда сижу и дою. Поэтому надо выбирать их'.

|l borr, - ar m. G 'хвоя’, borrar только мн. ч., f. 'репейники’ G [FREUDENTHAL, VENDELl 1886: 28]; bor, - $n$, - $a r,-a$ m., - $a$, -ar, -ana f. [DANELL 1951: 60].

15. brïf 'письмо' (< нем. Brief $\mathrm{m}$.): Egốr skrìva ja brîf ЛУ 'Я вчера написала письмо'; Ja för skrìv brîf 'Мне надо написать письмо'; Ja skrivva räi brif ЛУ 'Я уже написала письмо'; Tö kunt vär a hāve skreve brif ot me, xots tjü $\bar{u} d$ Лу 'Ты, наверно, мог бы написать мне письмо, хоть два слова'.

Исход на $f$ нехарактерен для исконных слов (brif-единственное существительное м. р. с таким исходом), в связи с этим у данного существительного определённая форма ед. ч. часто совпадает с неопределённой (§ 9): Ja skaffa briffbott ЛУ ‘Я отправила письмо’ (а не *briffen). В интервью с ЭУ это существительное является примером морфологической нестабильности. Форма brif была названа ею с неопределённым артиклем ж. p.: äin brïf, но с указательными местоимениями м. p.: tän brif 'это письмо', han brif' то письмо'; Kole har skrive tän brif ot däi? 'Кто написал тебе это письмо?'. Наряду с brif у ЭУ встретилась форма $b r \bar{e} v,-\ddot{a} r$ (< шв. brev): Ja $f i \bar{b} b \bar{v} v$ 'Я получила письмо'; Ja fōr mikke brēvär 'Я получаю много писем’; A te för tikkle brēvär? ‘А ты часто получаешь письма?’. При этом brēv было названо с указательным местоимением м. p. (тогда как шв. brev относится к ср. р.): tän brēv ‘это письмо', tän lōy brēe ‘это длинное письмо'.

$\|$ bräiv, -èr n. DGRO; braiv, -èr n. NO [FREUDENTHAL, VENDELL 1886: 33, 29]; briff, -en, - $a r,-a$ m. [KARLGREN 1953: 17]; braiv, -e, -er, -ena n. [DANELL 1951: 45].

16. brüsk (также n.) ‘хрящ’: Brüsken хрустит на зубах’. 
|| brüsk только ед. ч., n. DGNO [FREUDENTHAL, VENDELL 1886: 32]; brusk, -en, -ar, - $a$ m., -e, -er, -ena n. [DANELL 1951: 48]. О колебании между мужским и средним родом см. [МАньков 2010в: 94].

17. -bukk в för-bukk 'баран', gäit-bukk 'козёл', $h \bar{u} r-b u k k$ 'развратник', jüllbukk 'Дед-Мороз', sōg-bukk 'ко́злы'

\| bukk, -ar m. ‘козёл’ DGNORW [FREUDENTHAL, Vendell 1886: 34]; bok, -en, -ar//-er, -a//-e m. [DANELL 1951: 35].

18. bumm 'засов'. Встретилось только в интервью с МП. ЛУ называет форму на -ӧl, являющуюся новообразованием: (dänn-)bummöl, bummön/ -än, bummlar, bummlana, тип m.1c. Форма на -öl могла быть образована вследствие восприятия bummen как опр. ед. ч. не от bumm, а от bummöl (cp. liken, фонетически закономерное опр. ед. ч. к liköl 'ключ'). Ср. также trisk 'порог' вместо trisköl. Добавлению -öl могла способствовать также ассоциация с kvärvöl 'щеколда'.

|| bóm, -ar m. DGNORW, cp. bummstükk, -ar m. GO 'деталь ткацкого станка' [FREUdENTHAL, VeNDELL 1886: 29, 34]; bom, -en, - $a r$, - $a$ m. [DANELL 1951:36].

19. büll 'булочка': büll-bita m.3а 'кусок булки'.

\| büll, -ar m. G [FREUdENTHAL, Vendell 1886: 35].

20. bǘrak, rē-bürak ‘буряк, свекла’ (< рус.): Tom rē-büraka опр.мн. $k \bar{u} k a j a$ blöütar o sänn gjūd ja 'inn dom mä uksus o sugär... O vínegret me tom kūka

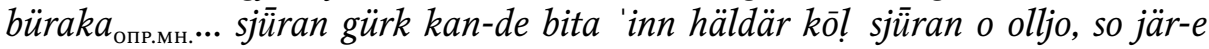
fädes ЛУ 'Я варила буряки пока они не становились мягкими, и затем заправляла их уксусом и сахаром... И винегрет с варёными буряками... можно покрошить солёный огурец или солёную капусту с маслом, и он готов'.

21. büsk 'куст’: bürjans-büsk ‘бурьян’ (отдельный куст); katüfl-büsk 'картофельная ботва'; kúraj-büsk ЛУ МП, kúrajs-büsk АЛ 'перекати-поле’; pigg-büsk 'лопух'; rūz-büsk 'розовый куст'; vínagrads-büsk 'виноградный куст'.

|| büsk, -ar m. DGNORW [FREUdENTHAL, VENDELl 1886: 36]; busk, -en, $-a r,-a$ m. [DANELL 1951: 61].

\section{2. bü̈k 'живот'}

|| búk, -arm. DGNORW [FREUDENTHAL, VENDELl 1886: 36], buk $k,-e n,-a r$, $-a \mathrm{~m}$. [DANELL 1951: 59].

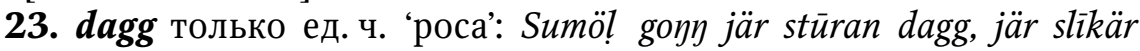
stūran, än fētäre blì vōtar ЛУ 'Иногда бывает сильная роса, такая сильная, что ноги становятся мокрыми'.

|| dagg только ед. ч., f. DGNORW [FREUDENTHAL, VENDELL 1886: 39]; dag, - $е$ только ед. ч., f. [DANELL 1951: 70]. О колебании между мужским и женским родом см. [МАньков 2010в: 94]. 
24. damm 'плотина': näsa-damm 'насморк'; To ja rokar o drär 'girm üte

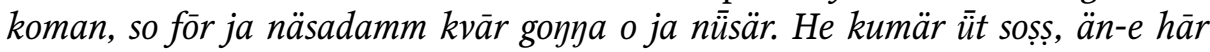
me gírm-dröe ЛУ 'Когда я купаюсь и в комнате сквозняк, у меня бывает насморк каждый раз, и я чихаю. Выходит, что меня просквозило'.

II damm, -ar m. GW [FREUDENTHAL, VENDELl 1886: 39; ISBERG 1970: 52].

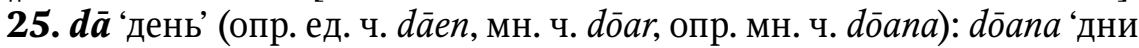
недели’; (h)edá 'сегодня'; fälse-dāen ‘день рождения’; namms-dā 'именины'; hölg-da 'праздник'; um dāen 'днём’; täsn/han dāen 'в этот/тот день'; tom dōana 'в те дни’; Gudá! 'Добрый день!'; Не blïär räi dā МП АЛ 'Уже рассветает’; Тот vār po lande tfo da [g]s-tī ЛУ 'Они были в степи два дня’; Färr vār-e ända ōat tìa lüsst, o nö bliär-e räi mörft um otta. Ko mike än dāen опр.в. räi bläi koțtare! ЛУ 'Раньше было светло до десяти, а теперь становится темно уже в восемь. Насколько день стал короче!'.

Названия дней недели встречаются в форме опр. ед. ч., с сокращением $\bar{a}:$ mondan, tìstan, unstan, tūsstan, frìdan, löüdan, sundan. Сюда же относится middan 'полдень'.

$\|$ dá, мн. ч. duar m. DGNO [FREUdenthal, Vendell 1886: 40]; dá, мH. ч. daar, daa(na) m. [KARLGREN 1953: 18]; da , -en, doar, doa m. [DANELl 1951: 70]. Обозначения дней недели у Венделля: månda, tísda, ónsda, tósda, frída, löwda, sunda. Карлгрен [KARLGREN 1953: 19] записал дни недели в форме, оканчивающейся на $r$ : mandar 'понедельник', так же midar 'полдень', и отнёс их к типу m. 5a (в нашей классификации m.2b). Однако в проведённых интервью формы на $r$ не были названы. У Данелля: mondar (опр.

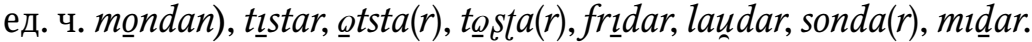

26. de 'смерть; покойник': dé-folk n. МП 'мёртвые'; Dèen опр.в. kuтӓr fikst МП 'Смерть придёт скоро'; Bōda jär... to dom bära dèen опр.вд. 'ü̈t, o frám-

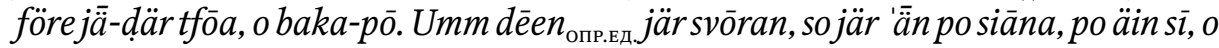
po ār sīa ЛУ ‘Катафалк - это... когда выносят покойника, и спереди двое, и сзади. Если покойник тяжёлый, то ещё по бокам, с одной стороны и с другой'.

II dé только ед. ч., m. DGNORW [FREUDENTHAL, VeNDELl 1886: 40]; de, -en, - $a r,-a$ m. 'труп' [KARLGREN 1953: 17]; de, -en m. [DANELL 1951: 85].

27. dill только ед. ч. 'укроп’: Go o plukk dill de 'hüp, ja tarvar de sjünn 'inn gürka ЛУ 'Иди и нарви укропа, мне надо засолить огурцы’.

|| dill только ед. ч., f. DGNORW [FREUDENTHAL, VENDELL 1886: 40]; в диалекте Нюккё записана только форма tiledn. [ISBERG 1970: 55]. О колебании между мужским и женским родом см. [МАньков 2010в: 94].

28. disk 'миска': bre-disk ‘блюдо для хлеба'; Hon rēd hūp sürest me grädd ot se de jäta, a tät-on komm, so vār-e räi änt üte disken творог со сметаной себе поесть, а пока она пришла, его уже не было на

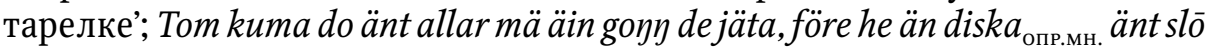




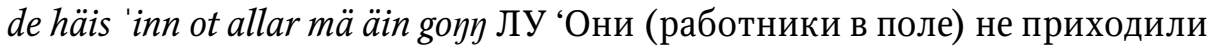
есть все сразу, потому что не хватало мисок, чтобы налить всем сразу'; Hon gì 'inn o lād 'hūp diska

\| disk, -ar m. DGNORW [Freudenthal, Vendell 1886: 41]; disk, -en, $-a r,-a$ m. [DANELL 1951: 75].

29. drēm 'сон': Ja sō-on änt lōya-tịär 'sjānd e drēmen видела во сне'.

II drém, -ar m. GRW [FREUDENTHAL, Vendell 1886: 43]; drainm, -en, -ar, $-a \mathrm{~m}$. [DANELl 1951: 80].

30. dubb 'пень' (встретилось в интервью с МП и АЛ)

\| Слово отсутствует у Венделля и Данелля. Ср. шв. dubb, -en, -ar 'колышек, деревянный гвоздь, клин, шип’ [SAOB: D2309].

31. dúrak/dǘrak 'дурак' [LAGMAN 1971в: 7].

|| durak только ед. ч., m. 'карточная игра' G [FREUDENTHAL, VENDELL 1886: 46]; durak, -en, -er, -e m. [DANELL 1951: 81].

32. dä̈i только ед. ч. 'тесто’: pankūks-däi ‘блинное тесто’; mēran däi

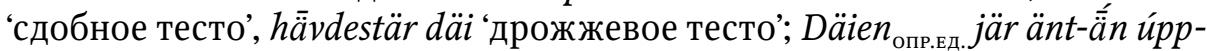
hä vdest ‘Тесто ещё не подошло’; Däien опр.в. jär räi hä̃vdestär, so gävär-e knōaen 'Тесто уже подошло, поэтому надо его месить'; To ja var lill, ja kumär e hōn-e, än gamma manyla mēran däi ütär kvațána po būde, o ja hōlt 'ō-e de jäta han rō däien опр.ед. Gamma gāv än bita o mäiär gāv-on änt ЛУ 'Когда я была маленькой, я помню, как бабушка раскатывала сдобное тесто на столе, и я любила есть сырое тесто. Бабушка давала кусочек, а больше не давала'.

Это существительное записано с м. р. во всех шведских диалектах Эстонии, тогда как между германскими языками существует колебание m.//n.: гот. daigs m., др.-шв. dēgher m., исл. deig n., фарерск. deiggj [tat:[] n. Колебание связано с тем, что прагерманские отглагольные существительные с суффиксом *- $a$ - (пие. *-o-; прагерм. *daig- 'тесто' связано с гот. digan 'месить') относились как к мужскому, так и к среднему роду, по-видимому, без какой-либо закономерности [MEID 1967: 60].

II däi, -ar m. DGRW [FREUdENTHAL, VENDELl 1886: 47]; dai, -en, -ar, - $a$ m. [DANELL 1951: 73].

33. däil 'часть': Ko mike jü̈n skülde ot de? - Än bra däil ЛУ 'Сколько он тебе должен? - Прилично'; Ve däila han bitan tjōl tfö däilar

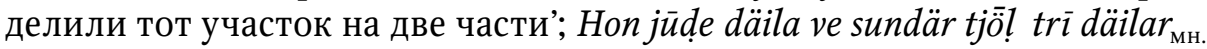
ЛУ 'Мы поделили участок на три части'.

|| däil, -ar m. DGRW [FREUDENTHAL, Vendell 1886: 47]; dainl, - $n,-a r,-a$ m. [DANELl 1951: 74].

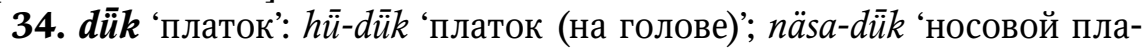

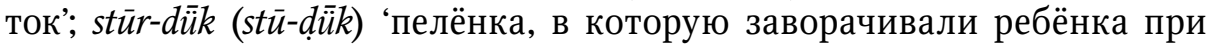


переноске’; Ja hār dü̈ken Ja hār allhundasláss dükar ${ }_{\text {мн., }}$ tjokkar o tunnar 'У меня есть любые платки, толстые и тонкие'.

\| dúk, -arm. DGNORW [Freudenthal, Vendell 1886: 46]; $d \underline{u} k,-e n,-a r$, $-a$ m. [DANELL 1951: 81].

35. famm 'охапка, руки': Ja tū he bōne upp po fammen опр.в. o ja var rädd, än ja äntfälldär 'nēr-e ЛУ 'Я взяла ребёнка на руки, и боялась уронить его'.

IIfamm, -arm. DGNOW [FREUDENTHAL, VENDELL 1886: 49]; fam, -en, -ar, - $a$ m. [DANELl 1951: 95]; fam, мн. ч. - $a$ m. [KARLGREN 1953: 19]; согласно примечанию Н. Тиберга, окончание - $a$ во мн. ч. встречается только после числительных [IBID.].

36. fisk 'рыба': salt-fisk 'рыба в рассоле, селёдка'; kūka fisk 'варёная рыба'; torrka fisk 'вяленая рыба'; Fär gī ve de mäit fisk Лу 'Раньше мы ходили ловить рыбу'; Ve vār po fiskjande egōr - Fī ne mike fisk fast? ЛУ 'Мы вчера были на рыбалке. - Много рыбы поймали?’; Fläkk fisken опр.ед. o tā $\bar{u} t$ tarma fron dom, a rummen läiv ōtär ЛУ 'Разделай рыбу и вынь кишки, а икру

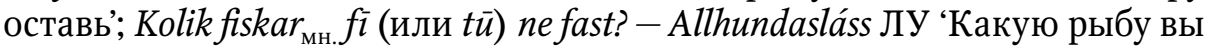
поймали? - Всякую'; Ja fōr rukk fiska опр.мн. ЛУ 'Мне надо почистить рыбу';

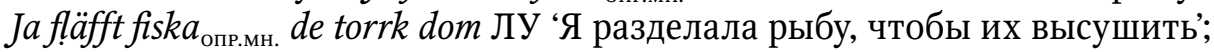
Tom rukkfiska оп.мн. o tōa üt tarma fron dom ЛУ 'Они чистят рыбу и вынимают кишки'.

|| fisk, -ar m. DGNORW [FREUDENTHAL, VENDELL 1886: 53]; fisk, -en, -ar, - $a$ m. [KARLGREN 1953: 17; DANELL 1951: 101].

37. frīṣtik АЛ МП, früsștikk и frișștik ЛУ ‘завтрак’ (< нем. Frühstück n.): Friștikk gäva dom mäst umm nīa ЛУ 'Завтрак чаще всего дают около девяти’; Ve vār po frișstiks jätande 'Мы завтракали'.

Il frístikk, -èr n. W [Freudenthal, Vendell 1886: 59]. В диалекте Нюккё 'завтрак' - тоres-(v)@- $q$, -no, - $a r,-a$ m. [DANELL 1951: 277]. Мужской род в современном диалекте вызван, возможно, влиянием русского слова.

38. fäil 'ошибка'

If fäil, - ar m. DGRW [FREUdENTHAL, VENDELL 1886: 62]; faıll, - $n$, - ar, - $a$ m. [DANELL 1951: 98].

\section{9. galg 'вешалка'}

|| galg, -ar m. DGNORW [FREUDENTHAL, VeNDELl 1886: 64]; galg, - $a$, - ar, -ana f. [DANELL 1951: 122].

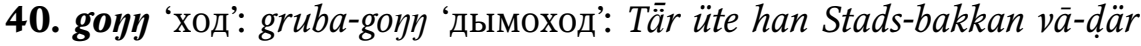
som än goyy de go 'inn üte-e, o tom tola, än türke grāva üt-n, o än-e vār so lāmft, än-e kumär 'üt ända üte stāen Bä' rislav. A kole väit, umm-e vār sannt häldär ljüd лу 'Там в крепости будто бы был ход, чтобы войти внутрь, и говорили, что турки выкопали его, и он был такой длины, что выходил в самом го- 
роде Бериславе. А кто его знает, правда или враки’; Han grubagoฑyen опред. vār fülldär mä ūs, o ja fì tōa 'üt-e Лу 'Дымоход забился сажей, и мне надо было вынимать её'.

|| gågg, мн. ч. не употребляется, m. 'ход’ G [FREUDENTHAL, VENDELL 1886: 75]; gogg, -en, -ar, -а ‘проход’ [DANELL 1951: 140].

\section{1. gö̈̈и 'кукушка'}

|| göuk, -ar m. DG [FREUDENTHAL, VENDELL 1886: 76]; guk, -en, -ar//-er, -a//-e m. [DANELl 1951: 144]; goek, gøk, -en, -ar, - a m. [ISBERG 1970: 110].

42. gübb 'старик': jūd-gübb 'клубника' (< шв.); tonte-gübb 'домовой' (другое обозначение - tont $\mathrm{m} .1 \mathrm{~b}$ ); $\ddot{A} n$ svāgär gübb, han gōr äfnast, män hār änt-ä́n sinne bótt-tappa ЛУ 'Дряхлый старик, он еле ходит, но ещё не выжил

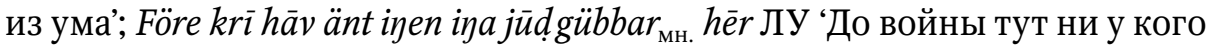
не было клубники'.

$\|$ gubb, -ar m. DGNORW [FREudenthal, Vendell 1886: 74]; güb, -en, - $a r,-a$ m. [DANELL 1951: 138]; go $\underline{b},-e n,-a r,-a$ m. [ISBERG 1970: 105]. Обозначения клубники: iódknapp, -ar m. GNO [FREUDENTHAL, VENDELL 1886: 95] (knapp - 'пуговица'); 10t-knap, -en, -ar, - $a$ m. 'земляника' [DANELL 1951: 184]; od-knap, lot-knap m. 'Fragaria viridis' [IsBERG 1970: 141].

43. gürk 'огурец' (< шв. gurka): O vínegret me tom küka büraka... sjüran gürk kann-de bita 'inn häldär kōl sjüran o olljo ЛУ 'И винегрет с варёными буряками... можно покрошить солёный огурец или солёную капусту с маслом'; Ja tarvar de sjün ' 'inn gürka ЛУ 'Мне надо засолить огурцы'.

\| gürk, -arf. G [FREUDENTHAL, VENDELL 1886: 74]; gurk, -a, -ar, -ana f. [ISBERG 1970: 106]. Мужской род этого существительного в современном диалекте объясняется влиянием русского слова [МАньков 2010в: 96].

44. hakk-spikk 'дятел'. Колеблется между типом m.1a (hakkspikk, -en, -ar, -a(na) ЛУ АЛ) и 2b (hakkspikkar, -spikkan, -spikkarär, -spikkana ЛУ), что вызвано переразложением во мн. ч.: hakkspikk-ar > hakkspikkar.

|| Венделль записал hakkspik m. только на Дагё, ср. hakkspit, -ar m.

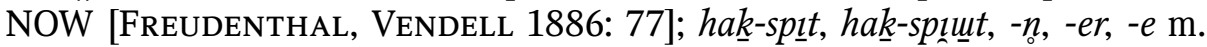
[DANELL 1951: 146].

45. halm только ед. ч. 'солома’: tröskakväits-halm ‘стебель кукурузы’ Ve täfftfärrtākena mä halm o räiar; soș täfft ve, höșs kvārkunnt'Раньше мы крыли крыши соломой и камышом; так крыли, как кто мог'; Äilda ve mä halm o mä kúraj ЛУ ‘Топили мы соломой и кураем’; Nōat fosar unde halmen опр.ед. kriss mäiädä́il МП 'Что-то шуршит под соломой, наверно крыса'.

\| halm только ед. ч., m. DGNORW [FREUDENTHAL, VENDELL 1886: 77]; halm, -en, -ar, - $a$ m. [DANELL 1951: 148].

46. hank 'вешалка'

\| hagk, -ar m. GN [FREUDENTHAL, VENDELL 1886: 78]; hagk, -en, -ar, -a m. [DANELL 1951: 152]. 
47. harkrank 'комар’: Flö̈una bürr, a harkranken

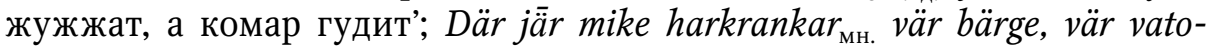
li ЛУ 'Много комаров на берегу, у воды’; Tär-úpp e Komi tär vār um dāen so mike harkrankar ${ }_{\mathrm{мн}}$, än de änt kunnt arbet, so gǟ-de upp äild, än-e rükär, o so arbeta-de üte räiken ЛУ 'Там в Коми днём было столько комаров, что невозможно было работать, поэтому разводишь костёр, чтобы он дымил, и работаешь в дыму'.

\| harkragk, -ar и -èr m. G [FREUDENTHAL, VENDELL 1886: 78]; hor-kragk, -en, -er, -e m. [DANELL 1951: 172].

48. holm 'плавня, заливной луг; остров’: Färr po holmen опр.вд. jāga dom $\bar{u} t$ buskan de vall se, tom roka ive vatne ot hon a-șia, o tom vār häila suman tär幽 Лу 'Раньше на остров выгоняли скот пастись, они переплывали на другую сторону, и они были всё лето там'.

$\|$ holm, -ar m. DGNORW [FREUDENTHAL, VENDELL 1886: 83]; holm, -en, - ar, - $a$ m. 'остров'; holmen - диалектное название о. Оденсхольм [DANELL 1951: 162]. Слово äi f. 'остров’, приводимое Венделлем [1886: 265], неизвестно современным носителям.

49. hōn опр. ед. ч. (от незасвидетельствованного *hō 'ум, память'), встречается только в выражении kuma e hōn-e, kuma de hōn-e 'помнить' 10 : "Ja minns" o "Ja kumär e hōn-e" - he kumär üt he äin ЛУ 'Ja minns и Ja kumär е hōn-е - это выходит одно и то же'; Tö kann do änt kuma dom de hōn-e allar, som kuma hitt-hếr näst oss Лу 'Разве их всех упомнишь, которые приезжают к нам'.

\| hå только ед. ч., m. 'ум', küma i hå $(n)$ GO [FreUdenthal, VeNDELL 1886: 88]; Koma ehóar [DANELl 1951: 179].

50. hüp 'куча': de 'hūp 'в кучу'; blōnd de hūp-e 'смешивать'; sūp hūp-e 'сметать (в кучу)'; Ja räpsa de 'hūp torr blānar som foll 'tjānd fron träna ЛУ 'Я сгребла в кучу сухие листья, которые опали с деревьев'.

\| hóp, -arm. GNOW [FREUdENTHAL, VendeLl 1886: 85; DANELl 1951: 162].

51. kalk только ед. ч. 'известь': Färr va-dür äit hōl, o üte he hole lād dom 'inn stäina o äilda, än dom bränn 'girm se. Han som änt brinndär 'üt, han bliär 'ō än stäin, o han som brinndär 'üt se kann-de sänn släkke de kalk: läggäde 'inn-en ot kallt vatn o so byrjar-en blodär o falldär ütär kvaț-ána, o he bliär sänn kalk. Färr vā-ḍär än bïl som kom o sjöd slìk stäinar de släkke kalk, o folke kēft tom ämbarena mä kalk-stäinar o släfft dom tär-häim. ЛУ 'Раньше была яма, и в ту яму клали камни и поджигали, чтобы они прогорали. Тот, который не прогорает, так и остаётся камнем, а тот, который прогорает, потом можно гасить: кладёшь его в холодную воду и он начинает кипеть и рассыпается, и потом получается известь. Раньше была машина, которая приезжала и продавала такие камни, чтобы гасить известь, и 
люди покупали вёдрами известковый камень и гасили его дома; Fä̈r klìstra dom träna po lande e trä-gōdn, a sänn läivd dom 'ò de klīstär, före he, än kalken $_{\text {опр.вд. }}$ bränndär barken ЛУ 'Раньше белили деревья в степи в саду, а потом перестали белить, потому что известь обжигает кору’.

\| kalk только ед. ч. m. DGNORW [FREUDENTHAL, VENDELL 1886: 99]; kalk, -en m. [DANELL 1951: 192].

52. kalv 'телёнок': Kalven опр.ед. kann stupp 'inn hüe ända de èrana üte kástrüll, a he tjokk jä-ḍo po bütne ЛУ 'Телёнок может засунуть голову до ушей в кастрюлю, густота же на дне'; Kvīka hār räi läifft, nö fōr ja räken, kodest än-on bär. Küda gōr mä kalven ${ }_{\text {опр.вд. }}$ tfo hundra otete fämm dōar ЛУ 'Тёлка уже погуляла, теперь надо считать, когда она отелится. Корова ходит с телёнком 285 дней'.

$\| k a l w,-a r$ m. DGNORW [FREUDENTHAL, VENDELL 1886: 99]; kal $v$, -en, -ar, - $a$ m. [DANELL 1951: 193].

\section{3. $\mathrm{kamm}$ 'расчёска'}

|| kamm, -arm. G, kám(b), -arm. GRW [FREUDENTHAL, VENDELL 1886: 99, 101]; kamb, -en, -ar, -a m. [DANELL 1951: 193].

54. kapp 'фуражка'

\|kapp, -arf. DG [FREUDENTHAL, VENDELL 1886: 100].

55. $\mathbf{k a r m}$ 'спинка кровати'

|| karm, -arm. DGNORW [FREUDENTHAL, VENDELL 1886: 100]; karm, -en, -ar, - $a$ m. [DANELL 1951: 195].

56. $\boldsymbol{k a s k}$ 'шуба' (< эст. kasukas [LAGMAN 1971A: 59]): Ve kēft kaska опр.мн. üte būe, to ve lēvd tär-úpp üte Komi. Äin goyn komm dom titt po arbete üte skūen o lād 'hūp tom kaska опр.мн. de ruka, o tät dom gī de tōa dom de kle 'pō dom de kēr häim, so vā-dom úpp-brunne: tom hogg kvüsta ō träna o kasta tom kvüsta de bränn 'upp, o äild-gnistana flü o flöü titt po han kask-rukan, o brann-e allt 'upp. Slüft komm-e 'üt näst oss ЛУ 'Мы покупали шубы в магазине, когда жили в Коми. Один раз они пошли на работу в лесу и сложили шубы в кучу, и когда пошли взять их, чтобы надеть и ехать домой, они (шубы) сгорели: они рубили сучья с деревьев и бросали те сучья жечь, и искры летают, и залетели туда на кучу шуб, и всё сгорело. Такое у нас случилось'

|| kask, -ar m. DGNORW [FREUDENTHAL, VENDELL 1886: 100]; kask, -en, -ar, - $a$ m. [DANELL 1951: 198].

57. $\boldsymbol{k i m p}$ 'горб' < эст. kimp [LAGMAN 1971A: 46].

|l kimp, -ar m. G [FREUDENTHAL, VENDELL 1886: 102].

58. klomp '(бесформенный) кусок’: is-klomp 'глыба льда'; möle-klomp 'облако'; To rǟvne gōrfärbì , o möleklompa 'upp, sūle byre räi skīn ЛУ 'Когда дождь проходит, и тучи расходятся, (небо) проясняется, солнце начинает светить' Konn tom möle-klompana лу ‘Откуда взялись те тучи?’. 
|| klümp, -ar m. G [FReUdenthal, Vendell 1886: 106], cp. klomp, -ar m. RW [IBID.: 105]; klromp, -en, -ar, -a m. [DANELL 1951: 203].

59. knapp 'пуговица': Knappen опр.вд. släitest 'ō, o nö för ja söüm 'fast-n ЛУ 'Пуговица отлетела, и теперь мне надо пришить её'.

|| knapp, -arm. DG [FREUDENTHAL, VENDELL 1886: 107]; cp. knepp, -en, -ar, $-a$ m. [DANELL 1951: 211].

60. $\boldsymbol{k n i \overline { v }}$ 'нож’: roka-kniv/rako-knīv 'лезвие'; tjöl-kniv 'нож для вырезания по дереву'; Där jär änt me ko de skära, där jär änt ina knīv Лу 'Нечем порезать, нет ножа'; Knīven опр.в. bläi bōlan, nö gävär-e kväss-n ЛУ 'Нож затупился, теперь надо заточить его’; Ja kvässa kniven опр.в. наточила нож напильником’.

Возможно, в диалекте существовала также форма с отпавшим $v$, *kni: cр. диалектную форму skrü 'шуруп' при шв. skruv. Согласный $v$ в $k n i v$ мог удерживаться под влиянием шв. kniv; форма с отпавшим $v, k n \underline{\underline{1}}$, записана Венделлем в диалекте Рюнё [VENDELL 1882-1887: 107]. Ср. также опред. ед. ч. $k n \bar{i}-n$ в диалекте Нюккё. Фонетически закономерным опред. мн. ч. являлось бы в этом случае *kni-na. Об этой форме косвенно свидетельствует встретившееся в интервью с ЭУ мн. ч. knīvnar, где $n$, возможно, взято из опр. мн. ч. ${ }^{*} k n i n a$ вследствие переразложения, а $v$ восстановлено под влиянием kniv: т. е. knivnar вместо *kninar, заменившим, в свою очередь, фонетически закономерную форму * $k n i a r$.

\| knív, -ar m. DGNORW [FREUDENTHAL, VENDELL 1886: 108]; knivv, -en,

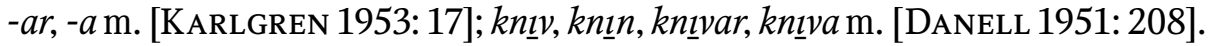

61. knupp ‘почка у растения’: tāk-knupp ‘конёк крыши’; Кпирра опр.мн. po träna slō 'ü̈tbittle um vōre. Där kann blīfrost, o kuna dom früs 'botț. Täta jär mäst po ablkốse, före-é dom blumsknas bittle ЛУ 'Почки на деревьях появляются рано весной. Может быть мороз, и они могут замёрзнуть. Это случается больше всего с абрикосами, потому что они рано цветут'; Кпирра опр.мн. tom byre räi spring ipetar, soșs-än ve siär, än trä jär levandest, än-e änt gī färlốra fron frostn ЛУ 'Почки начинают уже раскрываться, так что мы видим, что дерево живое, что оно не пропало из-за мороза'.

\| knüpp, -ar m. G, cp. knupp, -ar m. DNORW, tákknüpp, -ar m. G [FREUDENTHAL, VENDELL 1886: 109, 108, 230]; knup/knop, -en, - ar, - $a$ m. [DANELL 1951: 209].

62. kolb 'початок кукурузы’ (< нем. Kolben m.): Ja brük' (< brüka) kast 'inn tröṣakväits-kolbar ${ }_{\text {мн. }}$ som-en sole gnāvlar tjānd ЛУ 'Я имела обыкновение кидать кукурузные початки (в корыто свинье), которые она грызёт'; Mä tröṣkakväits-kolba ${ }_{\text {опр.мн. }}$ kann-de äild; kann-de dī 'inn-e e gasse o tjēn 'unde üen üte ställe pinnar ЛУ 'Початками кукурузы можно топить; можно обмакнуть в керосин и растапливать печку вместо щепок’; Ve brūd tröṣkakväits-aksna, o kolba опр.мн. $k$ ast ve 'üt. Mä tom kolba 
Tom kolba $a_{\text {опр.мн. }}$ kann ve sänn äild mä) ЛУ 'Мы лущили кукурузные початки и выбрасывали их. Этими початками можно топить'. $110]$.

\| kolb, -ar m. со значением 'гайка' G [FREUDENTHAL, VeNDELL 1886:

63. kópek 'копейка' (< рус., заимствовано в форме род. мн. копеек)

\| kopék, -ar m. DGNORW [FREUDENTHAL, VENDELL 1886: 110] (в этой форме $\bar{e}$ отражает рус. ее в копеек; в современном диалекте $е$ сократилось); kópek, -en, -ar, -a m. [DANELL 1951: 213].

64. kork 'каблук': Korken опр.ед.foll 'tjānd, he gävär spikk 'fast-n ЛУ 'Каблук отвалился, надо прибить его'.

\| kork, -ar m. DGNORW (к эст. saapakork) [FREUDENTHAL, VENDELL 1886: 111]; kork, -en, -ar, -a m. 'пробка' [DANELL 1951: 216].

65. korv 'колбаса': blü-korv МП 'кровяная колбаса'; kätt-korv 'обычная (мясная) колбаса'; livär-korv “ливерная колбаса'; räiftär korv 'копчёная колбаса'; räift korvar 'копченые колбаски'; Fron han räift korven опр.ед. han räika korven) kunt-de dämp katüflar mä ЛУ 'С копчёной колбасой можно

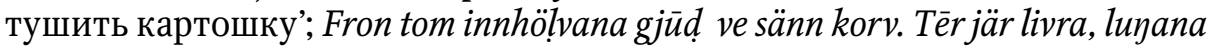
o sjätța o njürena (также njürana), he küka-de sänn o gär korv frōn-e, som dom säi livärkorv. Tèr kann ja 'ō kast 'inn he skinne som ja tū 'tjānd fron he tunn fläske som ja bräst 'üt de gräivar ЛУ 'Из внутренностей мы делали потом колбасу. Там печень, лёгкие и сердце и почки, ты это потом варишь и делаешь из этого колбасу, ливерную колбасу, как говорили. Туда я могу бросить и ту шкурку, которую я содрала с сала, которое я жарила на шкварки'; De gära kätkorvar ${ }_{\mathrm{Mн}}$, tā-de tom grann tarma, hälldä-de 'üt skōne o släim ütär tarma, vēndär 'umm dom ot ā-șia o ruka-dom, vaskar 'ò dom, än dom jära räinar. O sänn hälldär ja 'pō dom kalt saltat vatn, o üte he vatne läggär ja kvittlök 'inn. Tär jär he mola käte som ja har fä́des-lōa de gära korvar ${ }_{\mathrm{Mн}}$, o tär järr äit korv-hūn. Tö dräär titt po tät hüne tarmen o vrï̈r kät-kvēne, o he käte gōr 'inn ot tarmen, o ja bindär 'fast-n po ènda. O sänn kann-de räike dom ЛУ 'Чтобы сделать колбасу, берёшь тонкие кишки, вымываешь грязь и слизь, выворачиваешь их наизнанку и моешь их, промываешь, чтобы они были чистые. И затем я заливаю их холодной солёной водой и в ту воду кладу чеснок. Там перемолотое мясо, которое я приготовила, чтобы делать колбасу, и трубка. На эту трубку натягиваешь кишку и крутишь мясорубку, и мясо попадает в кишку, и я завязываю её на концах. И затем их (колбаски) можно коптить; Kätt-korv gära dom fron äina kätt, rett kätt. Brük' än slaft 'ō än kalv, o he käte 'ò mola-de 'sundär, o sänn gjüd. kätt-korv, räifft dom sänn ЛУ 'Мясную колбасу делали из одного мяса, красного мяса. Обычно резали ещё одного телёнка, и это мясо тоже перемалывали, и потом делали колбасу, её потом коптили'.

\| koriw, -ar m. DGNORW [FREUDENTHAL, VENDELL 1886: 111]; korv, -en, $-a r,-a$ m. [DANELL 1951: 218]. 
66. $\boldsymbol{k} \overline{\boldsymbol{o}}$ только ед. ч. 'древесная смола' (опр. ед. ч. kōn МП ЛУ, kōen АЛ): Tēr, konn blummen väksär, tēr kann-en jäta 'inn holär, me lōy-spitsat näsa, han makken, han jär sole gröär soșs-som barken jär po trä. O he torrkas 'botț, tēr blịär änt ina bärr de anos pō-e, o tēr kumär 'üt han kōn färlóra, han gräin ЛУ 'Там, где растёт цветок, он там может выедать дырки, долгоносик, тот жук, он сам серый как кора на дереве. И оно высыхает, там не будет ягод на другой год, и там выступает смола, немного, но она может пропасть, та ветка'.

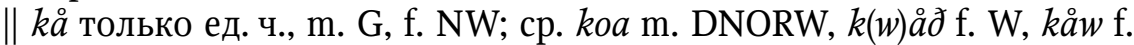
$\mathrm{N}$ [FReUdenthal, Vendell 1886: 109, 120]; $k \underline{o},-е$ только ед. ч., f. [DANELL 1951: 231]. Колебание между мужским и женским родом связано с существованием дублетов в древнешведском: kode m., kaadha $\mathrm{f}$.

67. $\boldsymbol{k r u \overline { u } \boldsymbol { k }}$ 'крюк': brunns-krūk 'журавль колодца'; Tom kēd 'ӥt mä tfo

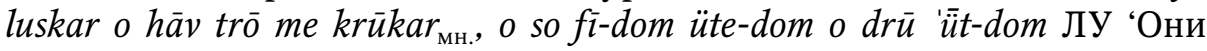
выехали с двумя лодками, и у них было корыто с крючьями, и они их (утопленников) нашли и вытащили'.

\| krók, -arm. DGNORW [FREUDENTHAL, VENDELL 1886: 114]; krok, -en, -ar, - $a$ m. [DANELL 1951: 222].

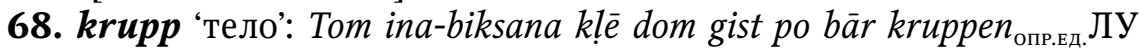
'Подштанники надевают прямо на голое тело'.

|| krupp, -ar m. DGNORW [FREUDENTHAL, VENDELl 1886: 115]; krup/ krup, -en, -ar, - $a$ m. 'тело; горб' [DANELL 1951: 223].

69. kupp 'горшок’: piss-kupp 'ночной горшок'.

|| kupp, -ar m. DGNORW [FREUDENTHAL, VENDELL 1886: 117]; kup, -en, -ar, - $a$ m. [DANELL 1951: 214].

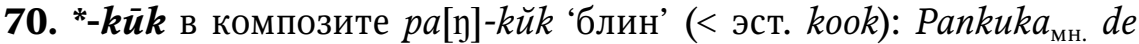
bräss, tār ja mölk o äggär (to de hār), o umm ja änt hār ina mölk, so tār ja vatn, lümmt. Tär kann ja slō ägg inn, umm ja hār, o kann de 'ó kast inn sugär. Män ja kasta änt ina sugär: to där jär sugär tär-ínn, so bli dom sètlètatar o kuna brännas fiksare po panna. O soṣs kasta ja änt ina sugär, bara soda o salt, o bräst dom, o mä he järr-e allt. Umm-de vill, so kann-de smäre dom mä povídl, häldär

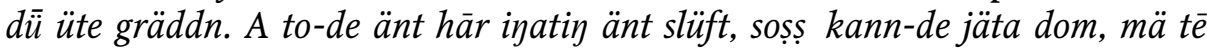
Лу 'Чтобы печь блины я беру молоко и яйца (когда есть), и если нет молока, то беру воду, не горячую. Туда можно разбить яйцо, если есть, и можно также бросить сахар. Но я не бросала сахар: когда там есть сахар, они становятся сладковатые и могут быстрее пригореть на сковороде. Поэтому я не бросала сахар, только соду и соль, и пекла их, и на этом всё. Если хочешь, можно намазать их повидлом или макать в сливки. А если у тебя нет ничего такого, можно есть их так, с чаем'.

\| kók, -arf. NOW [FREUDENTHAL, VENDELL 1886: 112]; k@k, - a, -ar, -ana f. [DANell 1951: 212]. 
71. kvit-lö̈̈k АЛ, kvitt-l[ø]k ЛУ, kvüt-lek АА только ед. ч. 'чеснок':

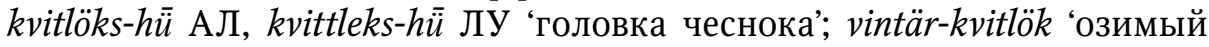
чеснок'; Skola-de räi 'ò kvitt-löken опр.в.? ‘Ты уже почистил чеснок?’; Mä kvitt-lök gär ja tom olljo-bolla. Ja kükar vatn upp, o üte he kūka vatne kastar ja 'inn salt to he jär räi ō-svolast. O sänn hälldär ja inn olljo o kastar kvittlök inn, sundär-klämdär, häldär stampar sundär tom kvittlöks-bitana. O sänn lägyäre ko? He som ja hāv boka de gära olljo-bollar, skär ja he sundär tjöl bitar o düpar 'inn-e üte he vatne ot äin sī o vēndär 'umm-e ot àr siăa, än-e bliär vott, o so kann-de jäta-e ЛУ 'С чесноком я делаю пампушки. Я кипячу воду, и в кипячёную воду, когда она уже остыла, бросаю соль. Затем лью масло и бросаю чеснок, измельчённый, или толку кусочки чеснока. И что дальше? То, что я испекла, чтобы делать пампушки, я режу на куски и макаю в ту воду, с одной стороны, и поворачиваю на другую сторону, чтобы оно стало мокрым, и тогда можно есть'.

Lö̈k используется только в этом композите; 'лук' - sip $l \mathrm{n}$.

72. lapp ‘лоскут’: notskinns-lapp ‘летучая мышь'; vask-lapp ‘тряпка для мытья посуды’.

|| lapp, -ar m. DGNORW [Freudenthal, Vendell 1886: 123]; lap, -en, -ar, - $a$ m. [KARLGREN 1953: 17; DANELL 1951: 241]. В диалекте Нюккё соответствием notskinnslapp является not-lapp, -en, -er, -e m., для которого Данелль наряду со значением 'летучая мышь' даёт значение 'козодой'.

73. lukk 'паук': Lukken опр.в. kann kannske bit, kannske jä-n giftatär. Po land-stikke, tär konn där jär gräss, tärr kann där skēas slüft ЛУ 'Паук, наверно, может укусить, он наверно ядовитый. В поле, там, где трава, такое может случиться'; Lukken опр.вд. finnar 'inn flöo de tōa 'fast-on ЛУ 'Паук опутывает муху, чтобы поймать её'.

\|l lükk, -ar m. G [Freudenthal, Vendell 1886: 132], cp. lukk, -ar m. DNORW [IBID.: 131]; lok $,-e n,-e r,-e$ m. [DANELl 1951: 252].

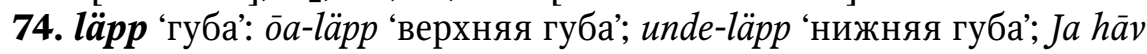

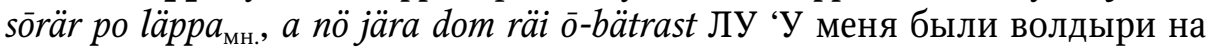
губах, а сейчас они уже зажили'.

|| läpp, -ar m. DGNORW [FReudenthal, Vendell 1886: 135]; loep, -en, $-a r,-a$ m. [DANELL 1951: 260].

\section{5. lügg 'чёлка'}

|| lügg, -ar m. DGNO [Freudenthal, Vendell 1886: 132], lug/log, -en, $-a r,-a$ m. [DANELL 1951: 255].

76. makk 'червяк; жук': rä̀ns-makk 'дождевой червь', skāl-makk 'улитка'; Där järr 'ō slìk makkar ${ }_{\text {мн. }}$ som tōa buskas-skōn o valtär 'ò mä-e, o he blïar sänn än runndär boll, han bollen blīär so stūran som äit vānätär. Han stōr po bāk-fêtäre o mä frama rülla-n o sküffar-e. Tom glima, jära som glima-lètatar. Ve slū do änt 'xjōl dom, a skōa grād po dom höș dom arbet ЛУ 'Есть также жуки, 
которые берут навоз и двигаются с ним, и он становится потом как шар, размером с грецкий орех. Он стоит на задних ногах и передними катит и толкает его. Они блестят, как бы немного блестящие. Мы их не убивали,

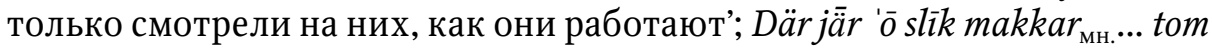
jära finäș-grūar, o unde büken hā-n fīn fētär, hōldä-șe po gräin fron ōapo o fron in-unde. Han jär sole ljüs-grēndär, a hösş-n häits väit ja änt. Tjōl bra jä̈-n do änt, ja gitsar soșs, ko kann-en gäva fär nitta? No där jär slikar ЛУ 'Есть и такие червяки... они в палец толщиной, и под животом у него ножки, держится за ветку сверху и снизу. Он сам светлозелёный, а как он называется не знаю. Ничего хорошего в нём нет, я думаю, что он может дать за пользу? Но есть такие’; Üte täss impa ablkốs têr blịä-dür makkar ${ }_{\text {мн. }}$ üte dom Лу 'В привитых абрикосах бывают черви'; Üte grina bläi där makkar ${ }_{\text {мн., }}$, tom makka jära kvitar, som ēylar ЛУ 'В крупе завелись червяки, те червяки белые, как личинки мухи'; Üte he mülke värke... brüka ve tōa 'üt makka

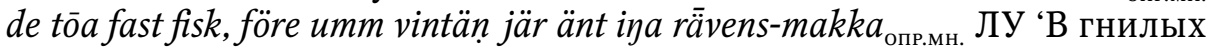
дровах... мы доставали оттуда червей, потому что зимой нет дождевых червей'.

|| makk, -ar//-èr m. 'червяк; змея' DGNORW [FREUDENTHAL, VENDELL 1886: 141]; mak, -en, -ar, -a m. [DANELL 1951: 268].

\section{7. $\boldsymbol{m o ̄ g}$ '}

|| måg, -ar m. DGORW [FREUdENTHAL, Vendell 1886: 149]; mog, -en, -ar, $-a \mathrm{~m}$. [DANELL 1951: 280].

78. munk 'монах'

|| mugk, -ar m. DGRW [FReUdenthal, Vendell 1886: 148]; mugk, -en, -ar, - $a$ m. ‘привидение' [ISBERG 1970: 211].

\section{9. $\boldsymbol{n a ̈ b b}$ 'клюв'}

|| näbb, -ar m. O [Freudenthal, Vendell 1886: 157]; noeb, -e//-a, -ar, -ana f., также n. [DANELL 1951: 296].

80. оbb 'окунь'

Эта форма встретилась только в интервью с ЛУ. В интервью с АЛ obbar m. 2b. Форма obb вызвана переразложением мн. ч. с нулевым окончанием, характерного для типа m.2b: obbar > obb-ar [МАньков 2013A: 23].

81. orm 'змея': Tom оrma опрмн. som jära po lande, tom jära änt stūrar o tom jära som gräse, grō-lètatar, än-de änt kann fō sì-en, tö kann stīv titt po-en, o hann kann bït-de. Tom säi, än dom jära giftatar. Män hēr har änt slüft skēd ЛУ 'Те змеи, которые в степи, они небольшие и они как трава, сероватые, так что ты можешь её не заметить и наступить на неё, она может укусить. Говорят, что они ядовитые. Но тут такое не случалось'.

\| orm, -ar m. DGNORW [FREUDENTHAL, VENDELl 1886: 160]; orm, -en, -ar, - $a$ m. [DANELL 1951: 303].

82. -pall в $\bar{u}$-pall 'выступ на печи, куда ставили посуду' 
II pall, -ar m. DO 'табуретка, скамеечка' [FREUDENTHAL, VENDELL 1886: 162]; -pal, -n, -ar, -a в sıppal-pal 'грядка лука' [DANELL 1951: 346]; pal m. 'грядка' (han grcevor pal ot kols-plrantana 'он копает грядку для капусты') [ISBERG 1970: 240].

83. pigg 'колючка': tri-pigar 'мелкие колючки'; Ja jāga inn tripigg üte finäre, o so bü̈na-e Лу ‘Я загнала колючку в палец, и оно нарывало’; Ja kän-

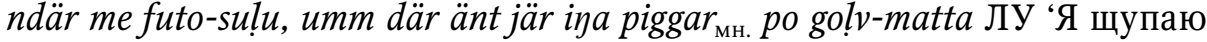

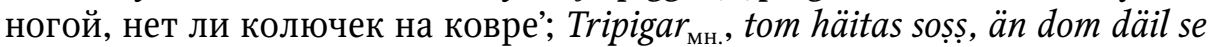
de trì bitar. Tom jära hōle spitsatar, to de stīvär titt pō-en, so kann där kuma üt

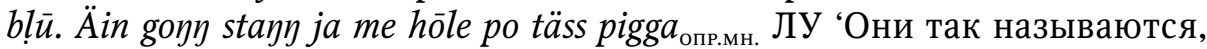
потому что они разделяются на три части; они очень острые, если на неё наступишь, может пойти кровь. Один раз я сильно укололась об эти колючки'.

II pigg, -ar m. DG [FREUDENTHAL, Vendell 1886: 163]; pig, -en, -ar, - $a$ m., -a, -ar, -ana f. [DANELL 1951: 310].

84. pírak 'пирожок' (< эст. pirukas [LAGMAN 1971A: 67]): äpl-pirak 'пирожок с яблоком'; Piraka опр.м. kann ja lägge titt än fämm-sjäks stikke. To dom lägge titt tom piraka опр.мн. panna de bräsas, so täkke dom 'fast loke po panna. O tät dom jära räi brünar brästest, so kann-e byre sprättas: to jära dom räi brünar. So tā-de 'tjānd loke o vēndär 'umm dom po a-șia, tom bli to blöütar ЛУ 'Пирожки не очень большие, я делаю их небольшими, поэтому могу положить туда (на сковородку) до пяти-шести штук. Когда кладут пирожки на сковородку жарить, закрывают крышку у сковородки. И когда они обжариваются, оно может начать трещать: тогда они уже коричневые. Тогда снимаешь крышку и переворачиваешь их на другую сторону, они делаются тогда мягкими; Gamma boka brē ot kolxóz, so boka-on pirakar ${ }_{\mathrm{мн}}$. mäseäitt ot oss tär-häim, o sole ve òt dom. Ko-on hāv, ko där vār, mä he boka hon tom piraka опр.мн., to mä sürüst, to mä bär, o to mä dämmtär kärps Лу ‘Бабушка пекла хлеб для колхоза и всё время пекла пироги для нас дома, и мы сами ели их. Что у неё было, что имелось, с тем она пекла пироги, когда с сыром, когда с ягодами, а когда с тушёной тыквой'.

I| pirag, -arm. DGNORW [FREUDENTHAL, VENDELL 1886: 163]; pírok, -en, -er, -e m. 'хлеб с запечённой рыбой или мясом' [DANELL 1951: 311]; piroksda! m. 'тесто для пирогов' [ISBERG 1970: 245].

85. pligg ‘колышек, клин’: To ja klüü̈r värke, o he vill änt klüas, so slōr ja 'inn tän pliggen опр.вд. $_{\text {. }}$ ЛУ 'Когда я колю дрова, и они не колются, то я забиваю клин'.

В интервью с МП встретилась форма kligg, вызванная, возможно, переходом $p>k$ под влиянием конечного велярного (дистантная ассимиляция). 
|| pligg, -arm. D [FREUDENTHAL, Vendell 1886: 165]; plıg/błlg, -en, - ar, - a m. 'клин; небольшой участок земли треугольной формы' [DANELL 1951:314].

86. pojke, опр. ед. ч. pojke, мн. ч. pojkar, опр. мн. ч. pojka(na) 'мальчик': brülops-pojke 'мальчик, сопровождающий невесту в церкви при бракосочетании'; skūl-pojke ‘школьник’; Üte hon träske drunkna 'ö än pojke ЛУ ‘В той речке утонул мальчик'.

Восходит к фин. poika, однако неясно, как именно слово попало в диалект. Если бы это было старое заимствование, безударный гласный должен был бы отпасть, однако форма * pojk не встретилась в интервью. Поэтому скорее всего слово было либо заимствовано из шв. pojke, либо получило конечное -е под его влиянием. Морфонологическая структура слова нетипична для диалекта (оно является единственным известным существительным м. р. с безударным -е после долгого корня), в связи с этим у него обычно отсутствует особая форма определённого ед. ч. (§ 9).

II poik, -ar m. DGNORW [FREUDENTHAL, Vendell 1886: 165]; poike, poıken, $-a r,-a$ m. [DANELL 1951: 315].

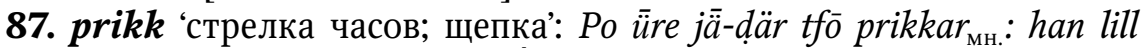
prikken опр.є. visar tïma, o han stür minüta ЛУ 'У часов две стрелки: маленькая показывает часы, большая минуты'.

II prikk, -ar m. DGNORW [FREUDENTHAL, VENDELL 1886: 166]; nceteprlk, -en, - $a r,-a$ m. 'поплавок у сети' [DANELL 1951: 298]; prik, -en, -ar, - $a$ m. 'точка': han sklaut mit e priken 'он попал в самую точку' [ISBERG 1970: 248].

88. pränik 'печенье' (< эст. präänik [LAGMAN 1971A: 67]): Färr vā-dür allhundasláss fron bläkke gjūd formar, o ve boka pränikar ${ }_{\text {мн. }}$ üte $\ddot{\ddot{e}}$. Tär vāadür slikar gjūdar som sjätțar üte se, som jütträ, äikjar, dukkar. Gamma bruka gära än som lärkja, mä vingar, o skār-on inn milla he stikke som vār tjöl stjätțn. Tjōll he de gära allt tarvas 'ō tïär ЛУ 'Раньше были всевозможные формы, сделанные из жести, и мы пекли печенье в духовке. Там были такие, которые были сделаны как сердечки, как ёлки, кони, куклы. Бабушка обычно делала ещё жаворонка, с крыльями, и вырезала в середине тот кусочек, который был хвостом. Чтобы сделать это всё, тоже нужно время’; Gamma tugga sundär pränikar ${ }_{\text {мн. }}$ o stuppa inn-ot üte munn, so bläi-en stilla o sunna 'ō. Gamma grummla, än-en jär huyra Лу 'Бабушка нажевала печенья и положила в рот (младенцу), он утих и уснул. Бабушка ворчала, что он голодный’; Fä̈r vādär änt ina pränika опр.мн, sole boka prätsla ЛУ 'Раньше не было пряников, мы сами пекли кренделя'.

|| broen-lk, -a, -ar, -ana f. ‘печенье с пряностями’ [DANELL 1951: 317]; prcenek/prcennik, -a, -ar, -ana f., -e, -er, -ena n. [ISBERG 1970: 249].

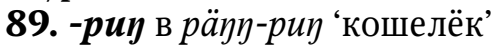

II pugg/pügg, -ar m. DGNORW [FREUDENTHAL, VENDELL 1886: 167]; pogg, -en, $-a r,-a$ m. [DANELL 1951: 318]. 
90. pältik/pältek 'туалет' (< эст. peldik [LAGMAN 1971A: 72]): Pälti$k_{\text {опр.ед. }}$ sank 'inn ot pältiks-hole ЛУ 'Туалет провалился в яму'; Pälteken опр.вд. jär bākum stjü̈е ЛУ 'Туалет за домом’.

I| pältik, -arf. DGNO [FREUDENTHAL, VENDELL 1886: 168]; pcelttk, - $a$, -ar, -ana f. [DANELl 1951: 309].

91. pülk ‘колышек' (<эст. pulk [LAGMAN 1971A: 85]): is-pülk 'сосулька'; Han pülken опр.ед. kann ja stupp 'inn ot jüde o bind 'fast än büsk, än-en änt falldär ütär kvaț-ána ЛУ 'Тот колышек я могу вставить в землю и привязать куст, чтобы он не разваливался'.

II pülk, -ar m. GNRW [FREUDENTHAL, VENDELL 1886: 167]; pulk, -en, -ar, $-a$ m. [DANELL 1951: 317].

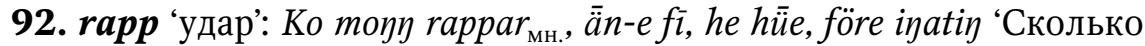
ударов получила она, эта голова, ни за что’.

|| Слово отсутствует у Венделля и Данелля. Ср. шв. rapp, -et 'удар палкой или кнутом' [SAOB: R286].

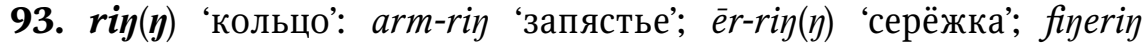

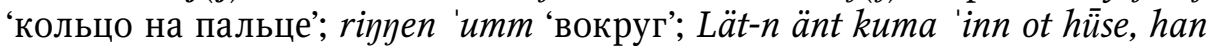
kann bli räddär, umm-en kumär 'inn, he jär allt solkat ringen опр.вд. 'uтm ЛУ 'Не пускай его в дом, он может испугаться, если зайдёт, вокруг грязь';

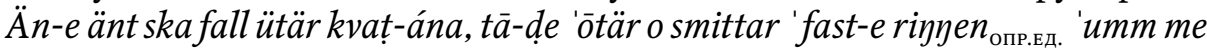
buskas-skōne Лу 'Чтобы он (навоз для отопления) не развалился, снова берешь и замазываешь его вокруг коровьим навозом’; Üte grima jä-dür

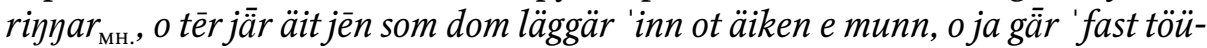

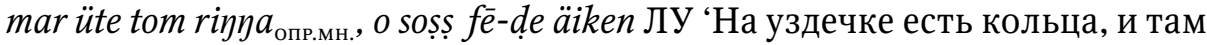
есть железка, которую укладывают коню в рот, и прикрепляют вожжи

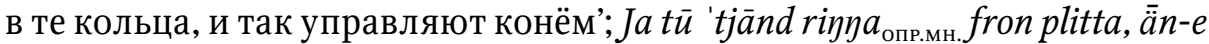
skilt kükfiksare 'Я сняла кольца с плиты, чтобы быстрее закипело'; Ja för

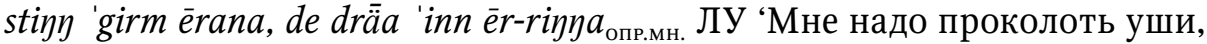
чтобы вставить серьги'.

|| rigg, -ar m. DGNORW [FREUDENTHAL, VENDELL 1886: 172]; rlgg, -en, $-a r,-a$ m. [DANELL 1951: 326].

94. rokk 'платье' (< нем. Rock m. ‘юбка; пиджак’ [LAGMAN 1973: 39]): halv-rokk ЛУ, halvär rokk АЛ 'юбка', ina-rokk 'женская нижняя рубашка'; Klänk 'inn tin rokk ot skōpe, än-en änt krimsas de 'hüp ЛУ 'Повесь своё платье в шкаф, чтобы оно не помялось'; Ja fräistar rokken платье'; Rokken опр.є..jär krimsatär ЛУ 'Платье помятое'; Tän rokken опр.єд.jär trāyasla ЛУ 'Это платье тесноватое’; Han var trāyasla ot-on, han rokken опр.вд. ЛУ 'Оно было тесновато ей, то платье'; Rokken en o földa 'umm-en po nitt ЛУ 'Платье было длинноватое, я подрезала его и подшила заново; Tom rokka опр.мн. vār-on grannare, a bläi äldäre, so bläai-on tjäkkäre. O hon kunt änt klē 'pō dom, 
o so söüma-on 'umm dom ot me Лу 'Те платья, в которых бабушка ходила раньше, когда она была молодая... она была стройнее, а когда стала старше, то стала полнее. И она не могла их надевать, и перешила их для меня'.

|| rokk, -ar m. f. DG, m. NO [FREUDENTHAL, VendeLl 1886: 174]; rok , -en, $-a r,-a$ m. [DANELL 1951:329].

95. rukk, spinn-rukk 'прялка' (также rukk-spinnar m.2b): To ja nistar tjānd gōne fron rukken опр.ед., so gär ja-e de härv, vaskar 'üt-e o gär-e de nikḷ ЛУ 'Когда наматываю нитки с прялки, то получается моток, выстирываю его и сматываю в клубок'.

|| rokk, -ar m. DGNO [FREUDENTHAL, VENDELL 1886: 174]; rok , -en, -ar, $-a$ m. [DANELL 1951: 328].

96. rumm, fisk-rumm только ед. ч. 'икра у рыб': Fisken jär mä rumm ütär se, ja hōldär 'o--en 'Рыба с икрой, я её (икру) люблю'; Fläkk fisken o tā üt tarma fron dom, a rummen опр.е. läiv 'ōtär ЛУ 'Разделай рыбу и вынь кишки, а икру оставь'.

|| romm только ед. ч., n. DG, m. RW [FREUDENTHAL, VeNDELL 1886: 174]; rom, -en, - $a r,-a$ m. [DANELL 1951: 329]. О колебании между мужским и средним родом см. [МАньков 2010в: 95].

97. räik только ед. ч. 'дым': He brinndä-ñoat, he lüftas ätt räik ЛУ 'Чтото горит, пахнет дымом'; He a vare bra, um-de a klistra-en, tè-de a sid, än

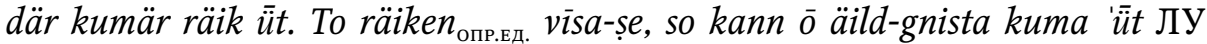
'Было бы хорошо, если бы ты её (трубу) побелил, там ты бы увидел, что выходит дым. Когда показывается дым, то может появиться и искра'.

|| räik только ед. ч., m. DGRW [FREUDENTHAL, VENDELL 1886: 178]; ra!k, -еп только ед. ч., m. [DANELL 1951: 341].

98. räim 'ремешок': Fron skinne skār ve färr räimar ${ }_{\text {мн. }}$ de drāa 'inn üte stövla, före där vār änt ina snērär de kēpas ЛУ 'Из кожи мы резали ремешки, чтобы вставлять в сапоги, потому что не было шнурков, чтобы купить'.

|| räim, -ar f. DGRW [FREUDENTHAL, VENDELL 1886: 179]; raım, -a, -ar, -ana f. [DANELL 1951: 323].

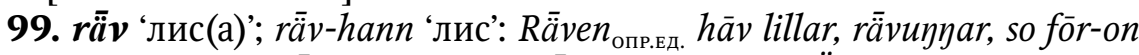
still dom, o kumär o stjōl botț hēna o bär ot tom unya... Ännan gì de tōa 'fast

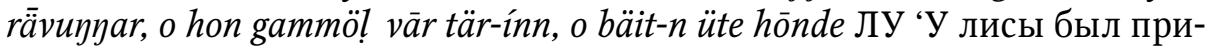
плод, лисята, ей надо их кормить, приходит и крадёт кур и несёт детёнышам... Один пошёл поймать лисят, а старая лиса была внутри и укусила его за руку’.

Это единственное существительное м. р., встретившееся со старым количественным чередованием $\overline{\mathrm{V}} \mathrm{C \#}$ (в неопр. ед. ч.) $\breve{\mathrm{V} C V}$ (во мн. ч.): $r a \bar{a} v, r a \tilde{u} v e n, r a ̈ v a r, r a ̈ v a$ в интервью с АЛ. В формах, названных МП и ЛУ, долгий гласный распространён на всю парадигму. Выравнивания в 
пользу долгого или краткого гласного произошли также в родственных диалектах.

\| ræv, мн. ч. räviar m. GNO [FREUDENTHAL, VENDELL 1886: 181], в диалекте Дагё обобщено $\ddot{a}:$ räv, мн. ч. räviar [IвID.: 180]; ravv, reven, revınar, revına m. [KARLGREN 1953: 18]; roev, -en, -er, -e m. (Нюккё), raev, rœven, roviıar, -ı (Ормсё) [DANELl 1951: 339]. В диалекте Нюккё обобщено $\bar{a}$, однако в композитах сохраняется $\ddot{\ddot{a}}$, например ræva-gat 'лисья нора'.

100. sakk 'coxa' < эст. sahk < pyc. [LAGMAN 1971A: 80, 185]

\| sakk, -ar m. G [FREUDENTHAL, VENDELL 1886: 181]; sak [KARLGREN 1924: 30]; sak, -a, -ar, -ana f. [DANELL 1951: 343].

101. sirop только ед. ч. 'варенье': kāvens-sirop 'арбузное варенье'; Mur-mūr häist 'inn fron kāven som dom küka... he kumär 'üt som kāvens-hunije

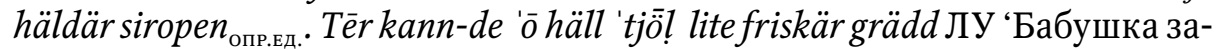
черпнула арбузного варенья, которое они варили... это, выходит, арбузный мёд или сироп'.

|| sirap только ед. ч., m. ‘сироп’ G [FREUDENTHAL, VENDELL 1886: 185]; sirap/sirop, -еп только ед. ч., m. [ISBERG 1970: 273].

102. skall, также hü-skall 'череп'

|| skall, -ar m. GW [FREUDENTHAL, VENDELL 1886: 189]; skal, -n, -ar, -a m. [DANELL 1951: 351].

103. skamm только ед. ч. 'стыд’: Ja hār skamm de tola mä-en 'Мне стыдно с ним разговаривать'; Üta skamm jära dom, umm dom kräve päynar frōn-en ЛУ 'Без стыда они, если требуют деньги с него’.

|| skamm только ед. ч., m. DGNORW [FREUDENTHAL, VENDELL 1886: 189]; skam f. [DANELL 1951: 351].

104. skē (-en, -ar, -a(na)) АЛ ‘постолы’ (обувь, которую носили в грязь)

Связано с др.-исл. skœði n. pl. ‘кожа для пары башмаков’, исл. skœði n. ‘постол, кожаный башмак', фарер. skøði ['skø:ji] n. 'кусок кожи или шкуры для башмаков; постол’, др.-гутн. scypi ‘обувь’ (прасканд. *skō-pij-ā, n. pl.). Образовано с помощью суффикса *-(i) $p j-a-$, имеющего собирательное значение; ср. лат. servitium 'рабство; рабы', lānitium 'шерсть' [KLUGE 1926: $\S$ 70; OLSON 1916: 267; MEID 1967: 149], от *skō- ‘обувь'. Мужской род этого существительного в современном диалекте вызван, возможно, ассоциацией co $s k \bar{u}$ 'башмак’.

|| ské, -r n. 'шнурок’ G [FREUDENTHAL, VENDELL 1886: 190].

105. skokk 'стадо’: buskas-skokk 'стадо’; än skokk äikjar 'табун'; Tom salla räi 'ò mä skokken опр.ед. ЛУ 'Стадо уже погнали'; Tom sall skokken опр.ед. po vallande um monnan, tjöl kvēldn gō dom räifiksare häim, skinde se häim, o so tarvar de änt jāg dom 'Стадо гонят пастись утром, вечером они уже идут домой быстрее, торопятся домой, и не надо их подгонять’; Ja sēft ätt min küda, hon komm 'inn se üte han skokken опр.ед., so fï ja skōa 'girm han buskas- 
skokken $_{\text {опр.ед. }}$ ЛУ 'Я искала мою корову, она попала в стадо, поэтому мне надо было пересматривать стадо’.

\| skukk, -ar m. GNR [FREUDENTHAL, VENDELL 1886: 197], cp. skokk, -ar m. DW [IBID.: 193]; skok , -en, -ar, -ana m. [DANELL 1951: 356].

106. skorop 'карп’ < укр. кópon?

\| skorop, -arm. G [FREUDENTHAL, VENDELL 1886: 193].

107. skorv только ед. ч. 'чесотка'

|| skorw только ед. ч., m. DGNORW [FREUDENTHAL, VeNDELL 1886: 193]; skorv, -en, - $a r,-a$ m. 'корка на ране; парша' [DANELL 1951: 357].

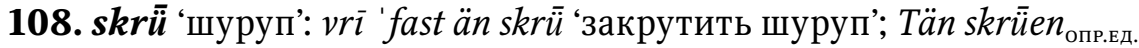
jär slikär rostatär blöe o vill änt vrias 'üt ЛУ 'Этот шуруп так заржавел, и не выкручивается'; Han tappa 'botț han skrüen опр.в., o ja hitt nö än āndär, o nö skrö̈ ja han skrüen опр.єд. 'fast ЛУ 'Он потерял болт, а я нашла другой и закрутила его'.

\| skrú, -ar m. DGNOLillRW [FREUdENTHAL, VENDELL 1886: 196]; skrü, -en, -ar, - $a$ m. [DANELL 1951: 359].

109. skū 'лес': skū-arbet 'работа в лесу': Grann-mü̈̈r sā ot me, höș-de kann klü 'sundär slìk stubbar? O ja sā ot-on: üte skūen опр.ед. $_{\text {. }}$ de arbet o änt vita, ko de gära me-e? ЛУ 'Соседка мне сказала: как ты разрубаешь такие пни? Я ей сказала: работать в лесу и не знать, что с ними делать?'

\| skó(g), -ar m. DGNOLillRW [FREUdENTHAL, VENDELL 1886: 194]; sk@, $-(e) n,-a r,-a$ m. [DANELL 1951: 356].

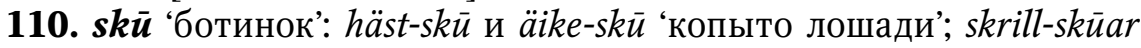
'коньки'; bind ' fast snērena po skū $a_{\text {опр.мн. }}$ ЛУ 'завязать шнурки на ботинках’;

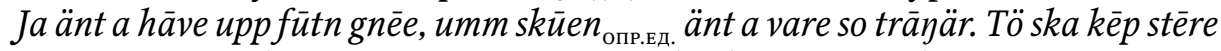
$s k \bar{u} a r_{\text {мн. }}$ МП 'Я бы не натёрла ногу, если бы ботинок не был такой тесный. Надо покупать туфли больше размером'; Tän sküen 'Этот ботинок жмёт'; Skūa опр.мн. kann vara stēsla oflott ot de ЛУ 'Туфли могут быть великоватыми и шлепать'; $S k \bar{u} a_{\text {опр.мн. }}$ klämm, tom jära minnsla Лу 'Туфли давят, они маловатые'; Täss skūa опр.мн. jära löüsare blöe, tom vār trāyasla fäst ЛУ 'Эти ботинки стали свободнее, они были тесноватые вначале’; $S k \bar{u} a_{\text {оп.мн. }} g n \bar{i}$ ЛУ ‘Ботинки трут’; Ja gnäi skinne 'tjānd mä skūa 'Я стёрла кожу ботинками'; Papa brüka kḹe 'pō se skrill-skūa me po isn po släan ЛУ 'Папа часто надевал коньки и катал меня по льду на санях'.

|| skó, -nar m. DGNO [FREUDENTHAL, VENDELL 1886: 194]; skü, -en, - ar, - a m. [DANELl 1951: 355].

111. skä̈l 'жеребец' (к нем. Schälhengst, согласно [FREUDENTHAL, VeNDELL 1886: 200]): Han drakk se drukkendär o lō o sō e grässe unde träna, näst Zina, o hon skälltest: hunda gäi, gāo änt ott-on de sōa. Slikär skäl jä̈-ṇ. Kann än ligge o löüäl, tät-n änt sunnar 'ó. Lüstet levand hā-n ЛУ 'Он напился пьяным 
и лежал и спал в траве под деревьями, у Зины, и она ругалась: собаки лаяли, не давали ей спать. Такой он жеребец. Ещё может лежать и петь, пока не уснёт. Весёлая у него жизнь'.

\|l skael, -ar m. DG [FREUDENTHAL, VENDELl 1886: 200]. В современном диалекте это слово произносится только с $l$ (а не $l$ ), что является признаком заимствования [МАньков 2010А: § 12]. В диалекте Нюккё “жеребец' - folra, -n, -r, -Ø m., vra!nsk, -en, -lar//-er, -la $a / /-e$ m. [DANELL 1951: 116, 471].

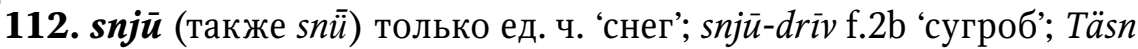
vintän hāv ve mike snjū ЛУ 'Этой зимой было много снега'; Snjū foll räi 'nēr, liggär räi so tjofft МП 'Выпал снег, лежит уже вот так высоко’ (букв. «толсто»); Snjūen опр.вд. foll 'nēr ЛУ 'Выпал снег'; Snjūen опр.ед. byrjas snatt lèn 'upp o smältär 'ó allan, he blïär snatt varmt 'Снег скоро начнёт таять и растает весь, скоро будет тепло'; Snüen опр.вд. léntest räi 'upp ЛУ 'Снег уже растаял'; Tom satt trä̈na 'inn, än snjūen опр.вд. $\ddot{a} n t$ iṣ umm häila lande. Umm tom

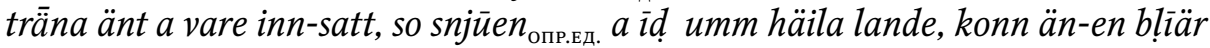
stōande. Vädere he blèsär o vrïär 'hūp-e allt, o soșș kann-e 'ō vrì 'hūp snjū-drīvar Лу 'Они сажали деревья, чтобы снег не мёл по всей степи. Если бы деревья не были посажены, снег мёл бы по всей степи, пока не остановится. Ветер дует и заметает всё, и может намести сугробы'.

|| snió только ед. ч., m. DGNOR [FREUDENTHAL, VENDELL 1886: 202]; snıֵ $\underline{\text {, }}$-en m. [DANELL 1951: 380].

113. snopp 'сноп’ (< pyc.): Färr vār-e soṣs - ina kombáinar vā-dür änt de slō kväite, so skār ve mä särp o band-e mä snoppar ${ }_{\mathrm{Mн} .}$ o sänn satt 'upp-e de stō, än-e torrkas 'üt bätrare Лу 'Раньше было так - не было комбайнов косить пшеницу, мы косили серпом и вязали снопами и потом ставили стоять, чтобы оно лучше подсыхало’.

\|snopp, -ar m. G [FREUDENTHAL, VENDELL 1886: 203].

114. spark ‘финские сани’ (на которых можно ехать самостоятельно, отталкиваясь, в отличие от släa) (<шв. spark):Ja hā $t f \bar{o}$ sparkar $_{\text {мн., }}$ än stūran o än litn. Po tän sparken опр.ед. kann ja kēr aläina, a po släan kann ja bara kèr 'nēr fron brantan Лу 'У меня было две пары финских саней, одни маленькие и одни большие. На sparken можно ехать самому, а на släan можно ехать только с горки'.

|l spark, -en, -ar, -a m. [ISBERG 1970: 299].

115. spikk 'гвоздь': slō 'inn spikken 'вбить гвоздь'; Ja släit 'sundär rokken, bläi hēyjande po än spikk häldär po än kvüst ЛУ 'Я порвала платье,

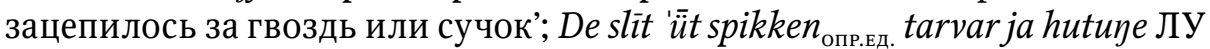
'Чтобы вытащить гвоздь, нужны клещи'.

|| spík, -arm. DG [FREUDENTHAL, VENDELL 1886: 207]. В диалекте Нюккё 'гвоздь' - nals m. ('ноготь' - figgo- $\eta \underline{a} l)$ [DANELL 1951: 286, 100]. 


\section{6. stamm 'ствол'}

|| stamm, -ar m. DGNORW [FREUDENTHAL, VENDELL 1886: 211]; stam, -en, -ar, - $a$ m. ‘форштевень’ [DANELL 1951: 392]; ‘ствол дерева’ в диалекте Нюккё - trą n. [IвID.: 441].

117. stīg 'тропинка': Ve trampa stīglāys mä brantan ЛУ 'Мы протоптали тропинку вдоль обрыва'; Stīgen опр.в.jär brantatär, so mnjü̈̈r, hēr kann-de änt $k \bar{e} r$ mä äikja, tèr fō-de bara gō defútts ЛУ 'Тропинка крутая, такая узкая, тут нельзя ехать на лошадях, можно только идти пешком’; Kott gōr han

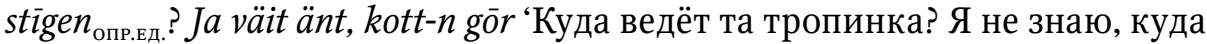
она ведёт'; Stīgen опр.вд. gōr lāys vär bärge o vrīs-n 'umm mut kirkja ЛУ 'Тропинка идёт вдоль берега и поворачивает к церкви'; He id. all stīgar he snìd o ìd, o har all stïgar ${ }_{\text {мн. }}$ fast-ìd. ЛУ 'Замело все тропинки, шёл снег и мело, и замело все тропинки'.

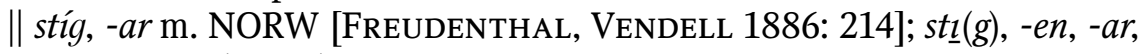
- $a$ m. [DANELL 1951: 395].

118. stjölk 'стебель'

|| stiölk, -arm. G [FREUDENTHAL, VENDELL 1886: 214]. В диалекте Нюккё 'стебель' - bł@m-skaft n., bł@m-stoka m. [DANELL 1951: 32].

119. strozak АЛ, strözak/ștrözak ЛУ 'матрас' (< нем. Strohsack): Näst tīske jär mūte mäst mä bülstrar de sōa pō-dom, täkke 'fast-de mä bülstär, o unde... O po sä̈ne in-onde 'ö üte ställe ștrözak ЛУ 'У немцев есть мода больше всего спать на перинах, укрываться периной, и внизу... И на кровати внизу вместо матраса'; Täkkjana söüm dom mä būmäl, o ștrözak gära dom 'ó mä būmäl. Fär vā-do töta änt, söüma fädes fron klēe o stuppa füllt mä halm, o po he sō ve sänn ЛУ 'Одеяла шьют из ваты и матрасы тоже делают из ваты. Раньше же этого не было, шили из ткани и набивали соломой, и на этом мы потом спали'; Färr stuppa ve inn-ot ștrözaken опр.в. halm, färr vā-där änt mä bummäl Лу 'Раньше мы набивали в матрасы солому, раньше не было (матрасов) с ватой'.

120. strunk 'кочан цветной капусты': kōl-strunk 'кочан капусты'

|| strågg, -ar f. 'стебель' G [FREUDENTHAL, VENDELL 1886: 217]; strogk, -en, -ar, - $a$ m. [DANELL 1951: 400].

121. stubb 'пень': värke-stubb 'чурбан': ...O rütndär stubb fron äit mülket trä (äit trä som var ō-brütest, o stubben опр.в. bläi), han kann 'ò glimpas, o to kumä-de titt närare, sïä-de, än-e jär än botț-mülkna stubb ЛУ 'И гнилой пень от трухлявого дерева (дерево, которое поломалось, и остался пень), оно тоже может светиться, и когда ты подойдёшь туда поближе, увидишь, что это сгнивший пень'; Tö hogg opố me värke po-en, po han stubben ättașt klöüstest- $n$ sole sundär ЛУ 'Ты рубила на нём дрова, на том чурбане, и наконец он сам раскололся'; Tär e Komi, so hakka ve 'üt tom stubba hakka ò rētäre riyyen 'umm o släit dom, som ve gjūd land ot oss de säte katüflar. 
Tär satt ve änt mäiär som katüflar ЛУ ‘Там в Коми мы выкорчёвывали пни, обрубали также корни кругом и вытягивали их, когда готовили себе поле сажать картошку. Там мы ничего не сажали кроме картошки'; Ро patța häldär gōse jär-e värre de skära me kniven, tēr hakka-de me ikse 'ò hüe, po än värke-stubb Лу 'Утку или гуся хуже резать ножом, там надо рубить голову топором, на пеньке’.

В интервью с МП это существительное относится к типу m.3b, т. е. названо с формой определённого ед. ч. на -an: stubb, stubban, stub$b a r, s t u b b a$ (как соответствующая форма в диалекте Нюккё, записанная Данеллем).

$\|$ stubba, $-r$ m. G, cp. stubb, -ar m. DNORW [FREudenthal, Vendell 1886: 217], stobb, -arm. NORW [IBID.: 214]; stub $\underline{b}$ sto $\underline{b},-a n,-a r,-a$ m. [DANELL 1951: 401].

122. stukk 'бревно’: bädo-stukk ‘бревно, к которому крепятся стро-

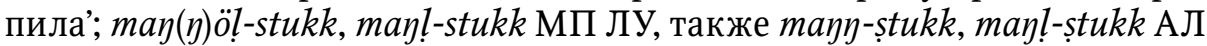

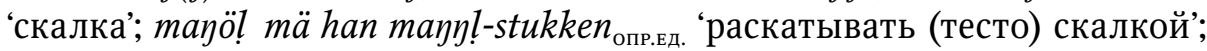

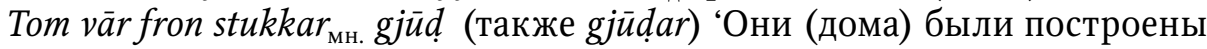
из брёвен'.

|| stükk, -arm. DGNORW [FREUDENTHAL, VENDELL 1886: 218]; stok-, -en, -ar, - $a$ m. [DANELL 1951: 396].

123. stump, bre-stump ‘горбушка': ...O sänn brē, ja brük' (< brüka) tōa stumpen $_{\text {опр.ед. }}$ O sänn sipl, kvitlük, salt o pipar. Täta knōar ja allt dehüp o bräsä-dọo лу '...И потом хлеб, я обычно брала горбушку. И потом лук, чеснок, соль и перец. Я это перемешиваю и тогда жарю’ (о приготовлении котлет).

|| stump, -ar m. O [FREUDENTHAL, VENDELL 1886: 218].

124. sukk 'чулок': Färr band ve sole sukkar ${ }_{\text {мн. }}$ o kapetar, üte būe vā-där änt de kēp. To tarva-de mike üll de spinn o bind ЛУ 'Раньше мы сами вязали чулки и носки, в магазине не было, чтобы купить. Тогда надо было много шерсти, чтобы прясть и вязать'.

\| sukk, -ar m. DGNORW [FREUdENTHAL, VENDELL 1886: 220]; sok, -en, -ar, -a m. [DANELL 1951: 381].

125. sva!m только ед. ч. 'пар’: To de kūkar, so svalma-de hōle... där jär mike svalm, tā finstäs-lükka ipet ЛУ 'Когда готовишь, идёт сильный пар... много пара, открой форточку’; To ja täkkär fast panna, so blïä-dür svalm po loke ЛУ 'Когда я закрываю сковородку, образуется пар на крышке’.

II svalm только ед. ч., m. 'пар; чад’ DGRW [FREUDENTHAL, VENDELL 1886: 222]; svalrm, -en//-an, -ar, -a m. [DANELL 1951: 407].

126. -svīg в knē-svìg 'коленный сустав’, riggebäins-svìg ‘позвонок’; Ja

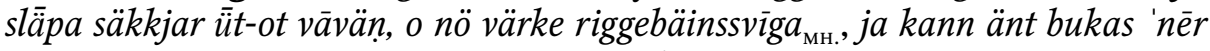
лу 'Я тягала мешки на телегу и сейчас болят суставы на спине, я не могу согнуться’. 
|| Слово отсутствует у Венделля и Данелля. Ср. исл. svigi m. 'прут; деревянный обруч', шв. svig ‘прут’ [SAOB: S15112].

127. svämm 'сон, состояние сна' (в отличие от drēm 'сновидение')

|| svämm только ед. ч., m. DGRW [FREUDENTHAL, VENDELL 1886: 224]; svœem, -еп только ед. ч., m. [DANELL 1951: 420].

\section{8. sï̈p 'рюмка'}

|| súp, -ar m. DGNORW [FREUdENTHAL, VENDELl 1886: 222]; supp, -en, -ar, $-a$ m. [DANELL 1951: 406].

129. șarf 'шарф, шаль' < рус.

II sarf [KARLGREN 1924: 48].

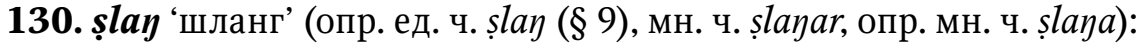
Ja lād 'inn șlay de släpp 'inn vatn ot tunna ЛУ 'Я положила шланг, чтобы набрать воду в бочку'.

\section{1. tagg 'колючка'}

|l tagg, -ar m. DG, f. NORW [FREUdENTHAL, Vendell 1886: 228]; tag, - $e$, -ar, -ana f. [DANELL 1951: 422].

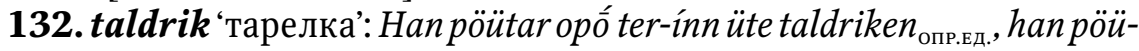
ta 'üt allt tjofft som vār e taldriken опр.вд., a he tunn läivd- $n$ ЛУ 'Он ковыряется в тарелке, выбрал всю густоту, которая была в тарелке, а жижу оставил'; Släik 'üt taldriken svine de jäta, he som bliär 'ōtär fron taldrikar ${ }_{\text {мн. }}$ ЛУ 'В корыто я наливаю свинье есть то, что остаётся с тарелок'.

|| Венделль не приводит этого слова для Старошведского. Ср. taldrèk $\mathrm{R}$, taldrik W, tallrék D, táldrikk N, táldrík O, мн. ч. -ar m. [FREUDENTHAL, VENDELL 1886: 229, 230]; taldrek, -en, -ar, - $a$ m. [DANELL 1951: 426].

133. tal g только ед. ч. 'говяжий жир, смалец’: Talgjä-dar üte buskan.

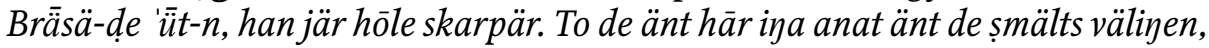
so kann-de ō 'he bräs inn-ot väliyen mä sīpl som de bräsär. To-en blïär kōldär, han välinen, so blïä-n som kölendär üte munn Лу 'Тaḷ, он у скота. Его выжаривают, он очень твёрдый. Когда нет ничего, чтобы зажарить суп, то можно и это зажарить в суп с луком, который пожаришь. Когда он становится холодным, тот суп, он вроде как облепляет рот'.

|| talg только ед. Ч., m. DGNRW [FREUDENTHAL, VENDELL 1886: 229]; talg, -en m. [DANELL 1951: 423].

134. tapp 'затычка'

|| tapp, -ar m. DGNORW [FREUDENTHAL, VENDELl 1886: 229]; tapp, -en, -ar, $-a$ m. [DANELL 1951: 426].

135. tarm 'кишка': blind-tarm ‘аппендицит'; grann tarmar ‘кишки’; Tom

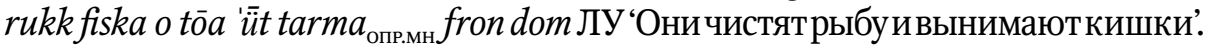

II taim, -ar m. DGNORW [FREUDENTHAL, VENDELL 1886: 230]; tarm, -en, -ar, - $a$ m. [DANELL 1951: 427]. 
136. tilk 'капля’ (< эст. tilk [LAGMAN 1971A: 100]): To panna jär häit me fäitn, ummja sprättartitt än tilkvatn, so sprättas-e ЛУ 'Когда сковородка горячая с жиром, если я брызну каплю воды, оно брызгается'.

|| tilk, -ar m. G, f. DNORW [FREUdENTHAL, VeNDELl 1886: 232]; $t \imath \underline{l},-n$, -ar, -a m., tılk, -a, -ar, -ana f. [DANELL 1951: 429].

137. tilp 'капля' (< эст. tilpama или tilpnema [LAGMAN 1971A: 117]):

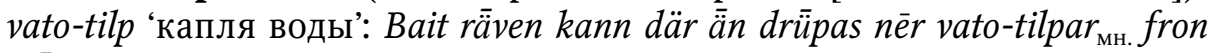
träna ЛУ 'После дождя могут ещё капать капли с деревьев’.

|| Вендель записал в Старошведском слабый глагол tilp 'капать' G [Freudenthal, Vendell 1886: 232]. Cр. tillp ‘капать’ (Дагё): sväid-dropana tillpa langsmä annlätna ‘капли пота стекали по щекам’ [LAGMAN 1971A:117].

138. tō 'фитиль': Ja vrïär 'inn han tōen опр.в. inn-ot lampa, a üte lampa fö-de häll 'inn gass, $\bar{a} n$-on brinndär Лу 'Я вкручу фитиль в лампу, а в лампу надо налить керосин, чтобы она горела'.

Возможно, это существительное первоначально относилось к слабому склонению (в современном диалекте тип т.3): ср. исл. togi m. 'нить; клок шерсти'.

|| tóg/tåg, - arf. W [FREudenthal, Vendell 1886: 236, 243]; tog, - $a$, -ar, -ana f. [DANELL 1951: 447].

\section{9. tōy ‘фитиль'}

Возможно, это существительное первоначально относилось к слабому склонению: ср. шв. tånge 'хвостовик, часть ножа, закреплённая внутри рукояти; мыс’; о принадлежности к слабому склонению свидетельствует также форма в диалекте Нюккё, имеющая определёный артикль -an.

|| tåggg, -ar m. ‘фитиль’ DGN [FReudenthaL, VendeLl 1886: 243]; toggg, -an, - $a r,-a$ m. 'фитиль; хвостовик’ [DANELL 1951: 448].

140. tropp 'пробка' (< эст. tropp < нем. Pfropfen m. [LAGMAN 1971A: 87]): tunn-tropp ‘затычка у бочки’

\|t tropp, -ar m. DGRW [FReudenthal, Vendell 1886: 238]; trop, -en, -ar, - $a$ m. [DANELL 1951: 440].

141. trō 'проволока' (опр. ед. ч. trōen ЛУ АЛ, trōn МП): Ja klämft 'upp klēna, grād soșs kasta 'upp-e ive trōen опр.єд., o hēyär dübät tēr, o nö jär ōa-sīa torr, a inn-unde jär-e vott. Nö för ja vēnd 'umm-e ot à-șia, före änkätț de klänke 'upp-e, jär trōen $n_{\text {опр.ед. }}$ so lögär ЛУ 'Я повесила бельё, просто перекинула через проволоку, и оно висит там сложенное вдвое, а теперь внешняя сторона сухая, и внутри сырое, мне надо перевернуть его на другую сторону, так как для того, чтобы вывесить целиком (т. е. не складывая) проволока слишком низкая'.

|| trå, -ar m. DGNO [FREUDENTHAL, VENDELl 1886: 239]; tro, -en, -ar, - $a$ m. [DANELl 1951: 441]. 
142. trülldūm 'колдовство'

|| trülldóm только ед. ч., m. DG [FREUdENTHAL, Vendell 1886: 239]; trol-dom m. [ISBERG 1970: 341].

143. túbak только ед. ч. 'табак'

II tobak G, tubak только ед. ч., m. GNRW, n. O [FREUDENTHAL, VENDELL 1886: 235, 241]; tobak/tubak, -еп только ед. ч., m. [DANELL 1951: 433].

144. tupp 'коса': Tom säi än-en kann pin äiken, än-enjär släkkande vōtär, az frāse jär po-en, o kann tipp tuppar ${ }_{\text {мн. }}$ po hāṣn ЛУ 'Говорят, что он (домовой) может мучить коня, что он (делается) совсем мокрый, аж пена на нём, и может плести косы на шее'.

|| tupp, -ar m. GO [FREUdEnTHAL, Vendell 1886: 242]; tup/top, -en, -ar, - $a$ m. [DANELl 1951: 434].

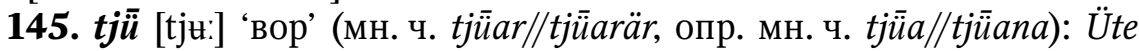
Komi vā-dür änt ina tjü̈ar $r_{\mathrm{мн}}$, före he än där änt vār ko de stjöla. Tärfí-de gära allt mä tin maft Лу 'В Коми не было воров, потому что не было что воровать. Там надо было всё делать своими силами'.

Форма мн. ч. на - $\operatorname{arär}$ (по типу m.2b) вызвана ассоциацией с такими существительными типа m.2b, как drikkjar 'пьяница', kükar 'повар' [МАньков 2013А: 22].

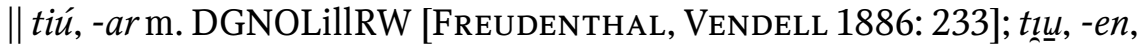
-ar, -a m. [KARLGREN 1953: 17]; tı $\underline{u}$, , -en, - $a r / /-e r,-a / /-e$ m. [DANELL 1951: 432].

146. $\boldsymbol{u b b}$ ‘филин’ (опр. мн. ч. ubba, а также ubbare по типу m.2b; cp. [МАньков 2013А: 22]): Ja gits' (< gitsa) än hund gäiär po bōna som skrī, a he vār

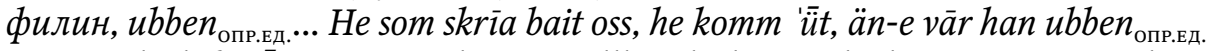
som gjūd slüft väzzent. Han skria po allhundasláss mōl: skriar o grōtär o lēär, allt... Ja tolar umm-e, o az än-e rü̈s̈̈r 'girm me ЛУ ‘Я думала, что собака лает на детей, которые кричат, а это был филин... То, что за нами кричало, оказалось, что это был филин, который делал такой шум. Он кричал на разные голоса: кричит, и плачет, и смеётся, всё... Я рассказываю об этом, и аж пробирает дрожь'.

$\| u b b,-a r$ m. G [FREUDENTHAL, Vendell 1886: 246]; $ø \underline{b}$, -en, - $a r,-a \mathrm{~m}$. [KARLGREN 1953: 17]; @m, -en, -ar//-er, -a//-e m. [DANELL 1951: 302].

147. varg ‘волк': varg-hann 'волк’ (самец); Hunda tjütsom varga ${ }_{\text {опр.ед., }}$ än-e jär grimmt de lias ЛУ 'Собаки воют как волки, так что страшно слушать'.

|| varg, -ar m. DGNORW [FREUDENTHAL, VENDELL 1886: 252]; varg, -en, -ar, - $a$ m. [DANELL 1951: 460].

148. varnek 'вареник' (к рус.): Han kōn kann-de bräs sänn pirakar mä, häldär gära varnekar ${ }_{\mathrm{Mн} .}$.Ja hōlt 'ò dom, varnekar ${ }_{\mathrm{мн}}$, grād mä äina ${ }^{11}$ kōl dämmtär mä täss gräivana ЛУ ' $\mathrm{C}$ капустой можно потом печь пироги или делать

11 Вместо äinan; форма женского рода ӓіna при существительном м. p. kōl 'капуста' вызвана влиянием русского существительного, относящегося к ж. p. 
вареники. Я любила их, вареники, только с одной капустой, тушёной со шкварками'.

149. vēg/väg 'дорога': grüs-vēg 'дорога, покрытая щебнем'; jēn-vēg ‘железная дорога'; koșṣ-väg ‘перекрёсток’; lü̈s-vä̈gAА АЛ ‘пробор на голове’ (шутливое обозначение; lüs - ‘вошь'); bräiär/mnjü̈̈r vä̈g ‘широкая/узкая тропинка'; po mitte-vägen/mitta-vägen 'в середине дороги’; Han gī ive vegen $_{\text {опр.єд. }}$ ЛУ 'Он перешёл через дорогу'; Hänaș grāv vār nä̈r vär vēgen 'Ее могила была у самой дороги'; Ko mike än tän vēgen 'Насколько эта дорога короче!'

|| vég DG, voeg DGNO, -ar m. [FREUdENTHAL, VENDELL 1886: 254, 261]; veg, -en, væegar, voga m. [DANELL 1951: 473].

150. vólok 'волок, рыболовная снасть' (< рус.): Tom gī dräa fisk mä

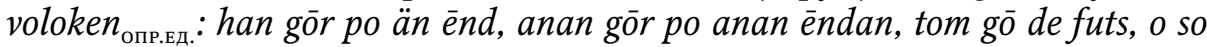
dräa dom 'ǜt-e po jūde, tèr jär-e füllt mä fisk, o so kast dom 'üt fiska po jūde. Sänn

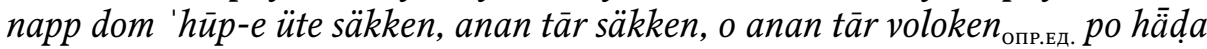
МП 'Они ходили ловить рыбу с волоком: один идёт с одним концом, второй с другим, они идут пешком, и вытягивают его на землю, там полно рыбы, и они выбрасывают рыбу на землю. Потом они собирают её в мешок, один берёт мешок, другой берёт волок на плечо’.

151. värk только ед. ч. ‘боль’: mōa-värk ‘боль в животе'; rigge-värk ‘боль в спине'; tann-värk 'зубная боль'; Ja hār riggevärk 'У меня болит спина'; То nōn hāv tannvärk, värft so hōle, so gī dom 'ō näst äina, o hon brauxa före tändäre, än dom änt ska värke ЛУ 'Когда у кого-то болели зубы, сильно болело, ходили к одной, и она шептала, чтобы зубы не болели'.

|| värk только ед. ч., m. DGNORW [FREUDENTHAL, VENDELL 1886: 260]; vark, -en, -ar, - a m. [DANELL 1951: 475].

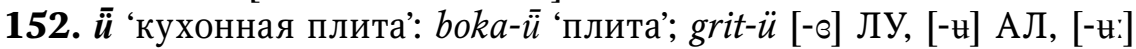
МП 'верхняя часть плиты’: Jä tjēnt unde gritüen brunne, he gävär häll 'inn kolär häldär lägge värke 'tjöl, jär räi kallt üte stjüe ЛУ 'Я зажгла плиту, а дрова уже прогорели, надо насыпать угля или добавить дров, в комнате уже холодно’; He brinndär räi änt üte gritüen jär räi üt-slukkna Лу 'Плита уже не горит... оно уже погасло'; Ja vill värm tekanna. Sätt titt-e po sīa, so jär-e do varmt, gritüen опр.ед. jä-do varmär ЛУ ' Я хочУ согреть чайник. Поставь его на край, чтобы оно было тёплое, плита же тёплая'.

Форма $\overline{\ddot{u}}$ (вместо * $\bar{u} n$; ср. приведённые ниже формы, записанные Венделлем и Данеллем) не является фонетически закономерной, так как в диалекте конечное $n$ в моносиллабах не апокопируется: ср. bjūn 'медведь', bö̈n 'фасоль', gräin 'ветка'. Данная форма вызывана восприятием * $\bar{u} n$ в качестве формы определённого ед. ч. с последующим переразложением * $\bar{u} n>\overline{\ddot{u}}-n$, откуда $\overline{\ddot{u}}$. 
Наряду с формой определённого мн. ч. $\overline{\ddot{u}} a(n a)$ в интервью с АЛ встретилось $\ddot{\ddot{u}}$ are, по типу m.2b; cp. ubb.

У существительного gritü встретились следующие формы: опр. ед. ч. grit-üen МП ЛУ АЛ; мн. ч. grit-ünar МП, grit-ür ЛУ, grit-ü(w)ar АЛ; опр.

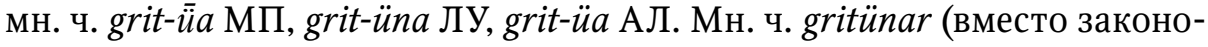
мерного gritüar) возникло вследствие переразложения формы определённого мн. ч. gritü-na > gritün- $a$, откуда неопределённое мн. ч. gritün-ar.

\| ún, -ar m. DGNO [FREUdENTHAL, VeNDELl 1886: 250]; $\underline{u} n,-\varnothing,-a r,-a$ m. [DANELL 1951: 450].

§ 11. Существительные на -i ков 2013A]):

1. armḷin 'сирота': Än armlin jär äit slüft bōn som jär üta fār o üta müär ЛУ 'Armlin - это такой ребёнок, который без отца и без матери'.

\| armligg, -ar m. G [FReudenthal, Vendell 1886: 17].

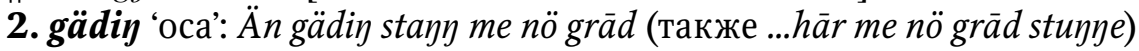
лу 'Меня только что ужалила оса'; Gädina ljana, tom fall 'nēr Лу 'Осы, они выедают дырки в грушах, и они падают'.

|| gäitigg, -ar m. DG, gätigg, -ar m. GRW [FREUDENTHAL, VENDELl 1886:

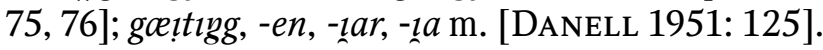

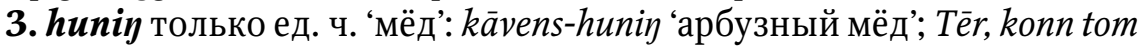
vill bia lād 'inn huniy üte räiana, tom gära 'fast he hole. To brük' (< brüka) ve säte stäan titt mūt vägge o skōa konn räiana jära 'fast, o so drū ve 'üt hon räia

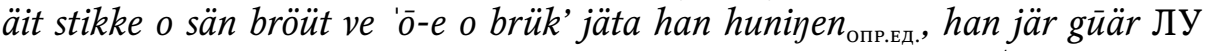
'Там, где дикие пчёлы положили мёд в камыш (которым были крыты крыши), они заделывают ту дырку. Тогда мы часто ставили лестницу туда к стене и смотрели, где камыши заделанные, и мы вытаскивали тот камыш, кусок, и потом отламывали его и ели тот мёд, он вкусный'.

|| hunigg только ед. Ч., m. DGW [FREUDENTHAL, VENDELL 1886: 86]; honogg, -еп только ед. ч. m. [DANELL 1951: 162].

4. $\boldsymbol{k i k}(\boldsymbol{k})$ !iy 'цыплёнок': Ja grina brē sundär ot kikklina крошила хлеба цыплятам’.

|| kikligg, -ar m. GOW [Freudenthal, Vendell 1886: 102]; в диалекте Нюккё 'цыплёнок' - hins-ogg m. [DANELl 1951: 178].

5. krimplì 'калека': Äina hēr, äin kälì, foll 'nēr o slū arms-bōan sundär.

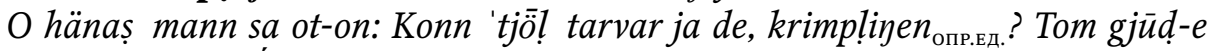
allt ot-on üte Käsșon, än armen arbetar näst-on 'ōtär o hon jä̈-ṇö stark. O ko skedd-e me han? He tū 'ó-en. O hon skōa nö 'ätt-n. Nö jä-n sole än krimplị. Han kan än rēä-șe, kann än gō sāfta. Han mado sole jäta, där vār ina tāl än 'umm-e. Slüft järr-e 'ò e vädn ЛУ 'Тут одна, одна женщина, упала и разбила локоть. А её муж сказал ей: «Зачем ты мне нужна, калека?» Они ей всё сделали 
в Херсоне, что рука снова работает у неё, и она выздоровела. И что случилось с ним? Его парализовало. И она за ним ухаживает. Сейчас он сам калека. Он ещё может двигаться, может ещё ходить медленно. Он может сам есть, об этом ещё не было разговора. Вот так тоже бывает на свете; Han vār krimplì, kunnt änt gō som-e gehēș ЛУ 'Он был калека, не мог ходить как надо'.

|| krimpligg, -iar m. DGNO [FREUDENTHAL, VENDELL 1886: 113].

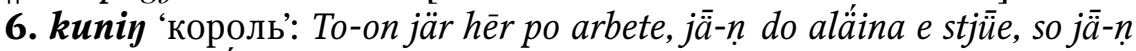
kunigen $_{\text {опр.вд. }}$ ter-hä́im ЛУ 'Когда она тут на работе, он (муж) один в доме, так что он дома король'.

\| kunigg, -ar m. G, также kunng, -arm. DGO, kugg, -ar m. GO [FREUDENTHAL, VENDELL 1886: 116]; konogg, -en, -ar, - $a$ m. [DANELL 1951: 213].

7. $\boldsymbol{m a ̈ \boldsymbol { x }}(\boldsymbol{x}) \boldsymbol{l i y}$ только ед. ч. 'оспа': mäxxliys-ärratär ЛУ 'со шрамами от

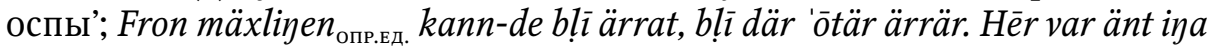
slikar som hāv slikk ärrär üte gezíchte ЛУ 'От оспы можно остаться с оспинами, остаются шрамы. Здесь не было таких, у которых были бы такие шрамы на лице'.

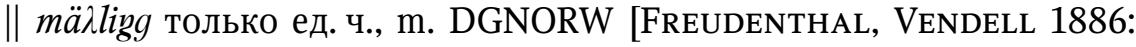
151]; malligg, -en m. [DANELl 1951: 284]. О сочетании -xxl- на месте шв. -sslсм. [МАньКов 2010A: § 20].

8. ōdnì только ед. ч. ‘порядок’ (< шв. ordning): gära ōdnị ‘наводить порядок'; Hon gī 'inn näst ännan, o satt dänna 'fast o regấra o gjūd ōdnị üte koman. Han komm 'inn o knoppa-en ot-on, so vār-on lōyä-țïär rädd Лу 'Она зашла тут к одному, закрыла дверь и хозяйничала и наводила порядок в комнате. Он вошёл и отдубасил её, поэтому она долго боялась'.

|| Cp. ånigg только ед. ч., f. D [FREUDENTHAL, VENDELL 1886: 263]; onigg, -e f. [DANELl 1951: 303].

9. släftì 'родственник'

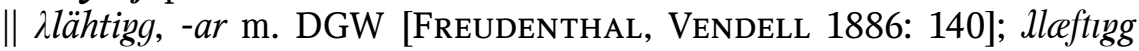
[DANELl 1951: 373].

10. späriy 'орёл'

|| spärigg, -ar DG, -iar NRW m. 'ястреб' [FREUdENTHAL, VeNDELl 1886: 210]; spærigg, -en, -lar, -la m. 'ястреб' [DANELL 1951: 390].

11. tfinniy АЛ МП, finniך ЛУ 'висок'.

В родственных языках соответствующее существительное имеет $t$ или $p$ в анлауте: др.-шв. thynning, thinning m.//f., шв. tinning, фарерск. tinning f., tinningur m., исл. punnvangi $\mathrm{m}^{12} \mathrm{~B}$ диалекте Старошведского начальное $t f$ - вместо фонетически закономерного $t$ - вызвано, возможно, ассоциацией с tfó ‘два' (виски как парная часть тела). Такому же измене-

12 Пример композита со сходным фонетическим развитием безударного гласного шв. köping < *kaup-angra-, букв. «торговый луг» [OLSON 1916: 259]. 
нию подверглось в диалекте обозначение плавника (также парный орган): tfinn f. при исходной форме finu. Ср. также формы глагола ‘скручивать две нитки в одну, сучить': finn наряду с tfinn. Что касается формы с начальным $f$ - - finning, - то она, в свою очередь, может быть вызвана ассоциацией с finu. Хелльквист также объясняет $t v$ - в соответствующих диалектных формах народной этимологией [HELLQUIST 1980: 975]. Альтернативное объяснение даёт Данелль: $t v-$ вследствие фонетической трансформации исходной формы, сохранённой в др.-исл. punnvengi [DANELL 1905-1934: 171].

|| tfinigg, -ar m. G [Freudenthal, Vendell 1886: 231], cp. finnigg, -ar m. DNO [IвID.: 52] и tvinigg, - $\operatorname{ar} \mathrm{m}$. W, -iar f. R [IBID.: 243], в диалекте Рюнё tinig m. [VENDELl 1882-1887: 141]; finigg, -en, -lar, -ta m. [DANELl 1951: 430].

12. tìdniy $\mathrm{m.} \mathrm{МП,} \mathrm{f.} \mathrm{АЛ} \mathrm{'газета'} \mathrm{(<} \mathrm{шв.} \mathrm{tidning):} \mathrm{Näst} \mathrm{oss} \mathrm{jä-där} \mathrm{än} \mathrm{mann,}$ han jär fron ațetande ōre, kumär-e 'üt, räi nitti-trī ōr... Han lās tìdniך üta öü-

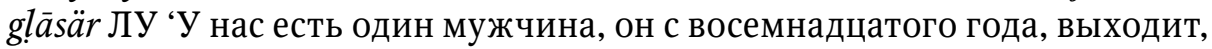
что ему девяносто три года. Он читал газету без очков'.

|l tildnigg f. [DANELL 1951: 429]. Другие обозначения газеты в диалекте Нюккё - aves, - $a$, -ar, -ana f., blra n., saıtogg, -a, -ar, -ana f. [DANELL 1951: $10,27,478]$.

13. tumliy ‘большой палец’

|l tumligg, -ar m. DGNORW [FREUDENTHAL, VENDELL 1886: 242]; tomlıigg, -en, - ar, - $a$ m. [DANELL 1951: 444].

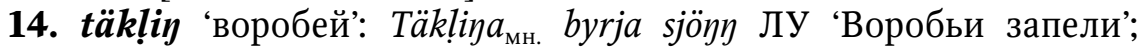

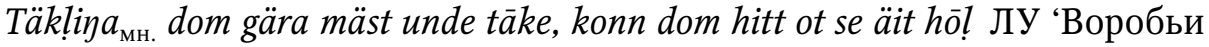
делают (гнёзда) в основном под крышей, где находят себе дырку'.

|| täkligg, -(i)arm. DGNORW [FREUDENTHAL, VENDELL 1886: 244]; toeklıgg, -en, -ar//-ıar//-er, -a//-ıa//-e m. [DANELL 1951: 449].

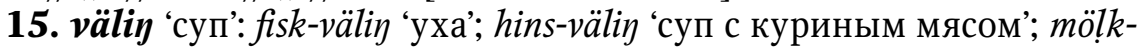

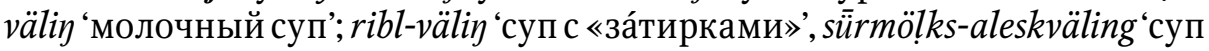
из кислого молока с галушками'; șmälsa väling 'суп с обжаренным луком и

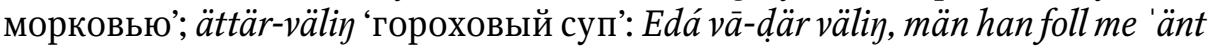
Лу 'Сегодня был суп, но он мне не понравился’; Väliyen опр.в. bläi allan, hōa räi 'ï̈t-n jäte ЛУ 'Суп закончился, весь уже съели'; Ja värmd välinen опр.ед. 'Я разогрела суп’; Välinen опр.ед. byrjar räi sjü̈̈̈n ‘Суп уже начинает прокисать’; Mä he bränn-nässle, to-e jär ä̀n umft, so kūk dom do 'ò väliy, kast dom 'inn-e üte

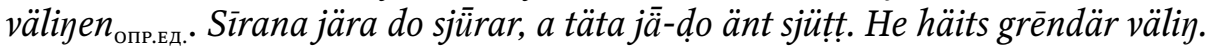
Tèr bita-de 'ò sipl-skaftär ЛУ 'Из крапивы, когда она ещё молодая, также варили и суп, бросали её в суп. Щавель же кислый, а она не кислая. Это называется зелёный суп. Туда крошат и зелёный лук'.

|| välg/väling/välgg, мн. ч. не используется, m. DGNORW [FREUDENTHAL, VENDELl 1886: 260]; voelyg, -en, - $a r$, - $a$ m. [DANELL 1951: 474]. 
§ 12. Существительные с -uך (ср. шв. -unge) [МАньков 2013А: 26]:

1. bjünuy 'медвежонок'

|l bion-ogg, -en, -ar, - $a$ m. [ISBERG 1970: 27].

2. bonuy 'детёныш'

3. füluy 'птенец'

4. grìsuy ‘поросёнок’ (наряду с grīs): Ivär än brāk so gävär ja dom ot-on,

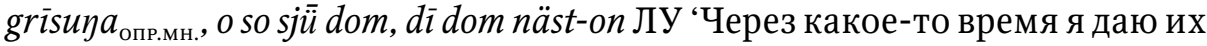
ей (свиноматке), поросят, и они сосут, кормятся у неё’.

|| gris-ogg [DANELL 1951: 132].

5. gäituy(y) 'козлёнок'

6. hundauy 'щенок'

В этом существительном обращает на себя внимание наличие соединительного гласного $a$ [МАньков 2013A: 27]. Cр. также hunda-tass m.1b 'лапа собаки', hunda-bissje f.2c 'собачья конура'. В других аналогичных композитах соединительный гласный отсутствует, ср., например, vargung 'волчонок'.

|| Cp. hündakwalp, -ar m. GRW [FREUdENTHAL, VendeLL 1886: 86]; hunda-ogg, -en, -ar, -a m. (наряду с hunda-holp m.) [DANELL 1951: 167].

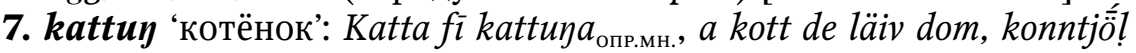
ivärmușs kattar? So tū ja o drämft 'ō dom, lād 'inn dom ot ämbare, loke po dom, än stäin po he loke, o hällt vatn 'inn po dom, o jär-e fädes, drunkna dom 'ō ЛУ 'Кошка принесла котят, а куда девать их, зачем слишком много котов? Поэтому я взяла и утопила их, положила их в ведро, сверху крышку, ещё камень на крышку, и налила воду, и готово, они утонули'; Kvār $h \bar{a} v$

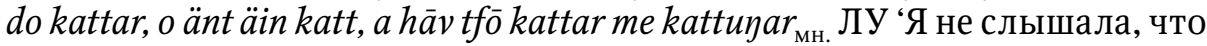
они тут были, крысы, у каждого были кошки, и не одна, а две, с котятами'; Katta liggär mä sin kattuךar ${ }_{\text {мн., }}$ tom kroka o sēke dì näst-on МП 'Кошка лежит со своими котятами, они лазят и хотят сосать молоко у неё'.

|| kat-ogg, -en, -ar, - $a$ m. [DANELL 1951: 200].

8. patțuy 'утёнок’: Ja rivvar sundär gürkar häldär kärpsar, sänn blōndar

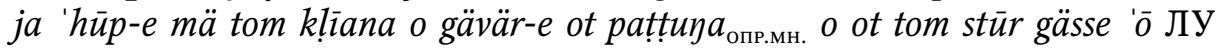
'Я натираю огурцы или тыквы, потом смешиваю с отрубями и даю это утятам и большим гусям тоже'.

|l pat-ogg m. [IsBERG 1970: 241].

9. skerattuy 'чертёнок; непослушный ребёнок': He hüse som Malmase leva jär äit gammät hüs, tēr bläi mama fēd o Äma-mustär, o tēr vār än bill, o han bill bläi blindär, soșs än han tū mamases papa näst se, än-en grāvar-en o hōldär upp-en de d[e] ts, o ska grāv nē-n, o he hüse bläi ot mamases fär. To han bill bèvd he hüse, so hāv-en arbets-folk som arbeta näst-n o lād he hüse 'upp ot-n. O han hāv änt 'üt-e bitaț allt som gehédest ot he folke, o so gāv dom ot-n... ja

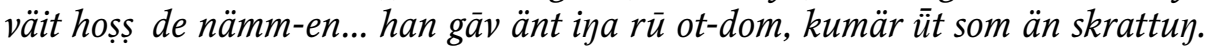


Mama toḷ umm, än tom kalla-en de rēär. O to-dom sō, so kunt-n kroka po-dom. Tom säi än-en kann pin äiken, än-en jär släkkande vōtär, az frāse jär po-en, o kann tipp tuppar po hāșn ЛУ 'Тот дом, где живут Мальмасы, - старый дом, там родилась мама и тётя Эмма (бабушка Лили Мальмас), и там был какой-то дед, и тот дед ослеп, так что он взял маминого папу к себе, чтобы он похоронил его и содержал бы его до смерти, и похоронил его, и тот дом остался маминому папе. Когда тот дед строил тот дом, у него были рабочие, которые работали у него и «выклали» тот дом ему. И он не выплатил всё, что надо было тем людям, и они дали ему... я не знаю, как его назвать... он не давал им покоя, выходит как чертёнок. Мама рассказывала, что они называли его рыжим. И когда они спали, он мог лазить по ним. Говорят, что он может мучить коня, что он становится совсем мокрый, аж пена на нём, и может плести косы на шее’.

10. täkliysuy 'воробьёнок'

|| trekllygs-ogg m. [ISBERG 1970: 347].

11. varguy 'волчонок'

|| vargugg, -ar m. DGNORW [FREUDENTHAL, VENDELL 1886: 252]; varg-ogg [DANELl 1951: 461].

§ 13. Существительные с суффиксом -läik (не используются во мн. ч.) [МАньков 2013А: 25]:

1. brēläik 'ширина'

|| В диалекте Нюккё - brald, - $a$ f. [DANELL 1951: 45].

2. djü̈pläik 'глубина'

|| diúpläik только ед. ч., m. G [FREUDENTHAL, VendeLL 1886: 41].

3. hö̈̈läik 'высота'

|| В диалекте Нюккё - hegd, -ñ m. [DANELl 1951: 177].

4. lōyläik 'длина'

|| loegd, -n m. [DANELL 1951: 260].

5. tjokkläik 'толщина'

6. vädärläik 'погода’: Vädärlaiken ändra-șe ЛУ 'Погода меняется’.

|| väðərläik только ед. ч., m. DGRW [FREUDENTHAL, VENDELL 1886: 259]; va-la!nk, -еп только ед. ч., т. [DANELL 1951: 473]. 


\section{Литература}

\section{ЗАБлОЦКИЙ 1838}

ЗАБлоцкий А., “Статистические сведения об иностранных поселениях в России”, Журнал министерства внутренних дел, 1838, 4/28, 5-6.

МАНЬКОВ 2010А

МАньков А. Е., “Диалект села Старошведское”, Вестник Православного СвятоТихоновского гуманитарного университета (= Вестник ПСТГУ). Серия III: Филология, 1 (19), 2010, 7-26.

МАНЬКОВ 2010В

МАньков А. Е., "Грамматические категории существительного в диалекте села Старошведское”, Вестник ПСТГУ. Серия III: Филология, 2 (20), 2010, 92-111.

МАНЬКОВ 2011А МАньков А. Е., “Словоизменение существительных в диалекте села Старошведское”, Вестник ПСТГУ. Серия III: Филология, 2 (24), 2011, 32-43.

МАНЬКОВ 2011в МАньков А. Е., “Диалект села Старошведское: материалы к описанию прилагательных и местоимений”, Вестник ПСТГУ. Серия III: Филология, 3 (25), 2011, 37-54.

МАНЬКОВ 2011с МАньков А. Е., “Диалект села Старошведское (Gammalsvenskby): отчёт о проекте”, XXI Ежегодная конференция ПСТГУ. Материалы, 2, 2011, 208-213.

МАНЬКОВ 2012A МАньков А. Е., “Словоизменение глаголов в диалекте села Старошведское”, Вестник ПСТГУ. Серия ІІІ: Филология, 2 (28), 2012, 7-25.

МАньков 2012в МАньков А. Е., "К описанию суффиксального словообразования существительных в диалекте села Старошведское”, ХХІІ Ежегодная конференция ПСТГУ. Материалы, 2, 2012, 159-161.

МАНЬКОВ 2013A МАньков А. Е., “Суффиксальное словообразование существительных в диалекте села Старошведское”, Вестник ПСТГУ. Серия III: Филология, 1 (31), 2013, 21-31.

МАНЬКОВ 2013В МАньков А. Е., “Проблема структурных изменений в исчезающем языке”, Вестник ПСТГУ. Серия ІІІ: Филология, 2 (32), 2013, 30-44.

НОВОРОССИЙСКИЙ КАЛЕНДАРЬ 1864

“Состояние народонаселения в колониях иностранных поселенцев южного края России в 1863 г.”, в: Новороссийский календарь на 1865 год, издаваемый от Ришельевского лицея, Одесса, 1864, 121.

ПИСАРЕВСКИЙ 1899 ПисАРЕвСкий Г., “Переселение шведов с острова Даго в Новороссийский край. По документам Государственного архива”, Русский Вестник, III, 1899, 246-252.

Список инородЦАм ЕвропЕйской России 1852 Список инородцам Европейской России, с показанием губерний, в которых они находятся, С.-Петербург, 1852.

\section{СПИСОК НАСЕЛЁННЫХ МЕСТ ХЕРСОНСКОЙ ГУБЕРНИИ 1917}

Список населённых мест Херсонской губернии по данным Всероссийской сельскохозяйственной переписи 1916 г. Издание Херсонской Губернской Земской Управы, Александрия, 1917. 
DANELL 1905-1934

DANELL G., Nuckömålet (= Svenska landsmål ock svenskt folkliv. B. 33), Stockholm, 1905-1934.

DANELL 1951

DANELL G., Ordbok över Nuckömålet (= Estlandssvenskarnas folkliga kultur, II. Skrifter utgivna av Kungl. Gustav Adolfs Akademien, 27), Uppsala, 1951.

Freudenthal, Vendell 1886

Freudenthal A. O., Vendell H. A., Ordbok öfver estländsk-svenska dialekterna, Helsingfors, 1886.

HANDBOOK OF IPA 1999

Handbook of the International Phonetic Association: A Guide to the Use of the International

Phonetic Alphabet, Cambridge, 1999.

HELlQUist 1980

HELLQUIST E., Svensk etymologisk ordbok, Lund, 1980.

Hultman 1894

Hultman O. F., De östsvenska dialekterna, Helsingfors, 1894.

Hultman 1939

Hultman O. F., Efterlämnade skrifter, 2. Föreläsningar över de östsvenska dialekterna, Helsingfors, 1939.

ISBERG 1970

IsBERG F., Supplement till G. Danells Ordbok över Nuckömålet (= Acta Academiae regiae Gustavi Adolphi, XLVII), Uppsala, 1970.

KARLGREN 1924

KARLGREN A., “Gammalsvenskby: Land ock folk”, Svenska landsmål ock svenskt folkliv, 1924, $1-64$.

KARLGREN 1953

KARLGREN A., Gammalsvenskby: Uttal och böjning i Gammalsvenskbymålet (= Svenska landsmål och svenskt folkliv. B. 56), Stockholm, 1953.

KLUGE 1926

KLUGE F., Nominale Stammbildungslehre der altgermanischen Dialekte (= W. BRAUNE (Hrsg.), Sammlung kurzer Grammatiken germanischer Dialekte. Ergänzungsreihe, I), 3. Aufl., Halle (Saale), 1926.

LAGMAN 1971A

LAGMAN H., Svensk-estnisk språkkontakt. Studier över estniskans inflytande på de estlandssvenska dialekterna (= Acta Universitatis Stockholmiensis. Stockholm Studies in Scandinavian Philology. New series, 9), Stockholm, 1971.

LAGMAN 1971B

LAGMAN H., "Ryska lånord i estlandssvenska mål”, Svio-estonica. Studier utgivna av svenskestniska samfundet, XX, ny följd 11, 1971, 3-29.

LAGMAN 1973

LAGMAN H., “Tyska lånord i estlandssvenska mål”, Svenska landsmål och svenskt folkliv, 1973, 11-57.

E. LAGMAN 1979

LAGMAN E., Estlandssvenskarnas språkförhållanden (= En bok om Estlands svenskar, 3a), Stockholm, 1979.

MEID 1967

MEID W., Germanische Sprachwissenschaft, III, Wortbildungslehre, Berlin, 1967. 


\section{OLSON 1916}

OLsON E., De appellativa substantivens bildning ifornsvenskan: Bidrag till den fornsvenska ordbildningsläran, Lund, 1916.

O’SHANNESSY 2011

O'SHANnEssy C., "Language Contact and Change in Endangered Languages”, in: P. K. Austin, J. SAllabank (eds.), The Cambridge Handbook of Endangered Languages, Cambridge, 2011, $78-99$.

\section{SAOB}

Ordbok över svenska språket utgiven av Svenska akademien, I- , Lund, 1893- .

TiBerg 1962

TIBERg N., Estlandssvenska språkdrag (= Acta Academiae regiae Gustavi Adolphi, XXXVIII. Estlandssvenskarnas folkliga kultur, 6), Lund, 1962.

\section{VENDELL 1881}

VENDELL H., Laut- und Formlehre der schwedischen Mundarten in den Kirchspielen Ormsö und Nukkö in Ehstland. Academische Abhandlung, Helsingfors, 1881.

VENDELL 1882-1887

Vendell H., Runömålet. Ljud- ock formlära samt ordbok (= Nyare bidrag till kännedom om de svenska landsmålen ock svenskt folkliv, II.3.), Stockholm, 1882-1887.

VENDELL 1904-1907

VENDELL H., Ordbok över de östsvenska dialekterna, I-IV (= Skrifter utgivna af Svenska litteratursällskapet i Finland, LXIV, LXXI, LXXV, LXXIX), Helsingfors, 1904-1907.

Александр Евгеньевич Маньков, канд. филол. наук ст. преп. кафедры германской филологии филологического факультета Православного Свято-Тихоновского гуманитарного университета 109651 Москва, ул. Иловайская, д. 9, корп. 2

Россия / Russia mankov-pstgu@hotmail.com 